\title{
Differentiating Psoriatic Arthritis from Osteoarthritis and Rheumatoid Arthritis: A Narrative Review and Guide for Advanced Practice Providers
}

\author{
William Saalfeld · Amanda M. Mixon · Jonna Zelie · Eileen J. Lydon
}

Received: June 11, 2021 / Accepted: August 24, 2021 / Published online: September 14, 2021

(C) The Author(s) 2021

\begin{abstract}
Psoriatic arthritis (PsA) is a chronic inflammatory disease that affects multiple organ systems and is characterized by skin and joint manifestations. PsA is frequently undiagnosed and/or misdiagnosed, especially because of the similarities in clinical presentation shared with other arthritic diseases, including rheumatoid arthritis (RA) and osteoarthritis (OA). An accurate and timely diagnosis of PsA is crucial to prevent delays in optimal treatment, which can lead to irreversible joint damage and increased functional disability. Patients are usually seen by a number of different healthcare providers on their path to a diagnosis of PsA, including advanced practice providers (APPs). This review provides a comprehensive overview of the characteristic features that can be used to
\end{abstract}

W. Saalfeld $(\square)$

Arthritis Center of Nebraska, 3901 Pine Lake Road, Suite 120, Lincoln, NE 68516, USA

e-mail: William.Saalfeld@nebraskaarthritis.com

\section{A. M. Mixon}

Arthritis and Rheumatology Clinic of Northern

Colorado, Fort Collins, CO, USA

J. Zelie

URMC Division of Rheumatology, Rochester, NY,

USA

E. J. Lydon

NYU Langone Medical Center, New York, NY, USA facilitate the differentiation of PsA from RA and OA. Detailed information on clinical manifestations, biomarkers, radiologic features, and therapeutic recommendations for PsA included here can be applied in routine clinical settings to provide APPs with the confidence and knowledge to recognize and refer patients more accurately to rheumatologists for management of patients with PsA.

Keywords: Psoriatic arthritis; Diagnosis; Rheumatoid arthritis; Osteoarthritis; Clinical presentation 


\section{Key Summary Points}

Psoriatic arthritis (PsA) is a complex disease characterized by inflammation of multiple clinical domains, including peripheral joints, skin and nails, axial joints, entheses, eyes, and digits

The similarities in clinical presentation of PsA and other rheumatic diseases such as rheumatoid arthritis (RA) or osteoarthritis (OA) can make a differential diagnosis challenging; therefore, it is crucial for primary care providers, including advanced practice providers (APPs), to be aware of characteristics and criteria indicative of a diagnosis of PsA

Characteristic features can be used to differentiate PsA from RA and OA, and early assessment, diagnosis, and treat-totarget strategies are key to the management of patients with PsA to facilitate the administration of appropriate therapy in a timely manner

Collaboration and coordinated care are key among primary care providers, APPs, and subspecialists to ensure positive outcomes for patients, controlling symptoms and disease activity, maintaining functional ability, and improving patient quality of life

\section{INTRODUCTION TO PSORIATIC ARTHRITIS, RHEUMATOID ARTHRITIS, AND OSTEOARTHRITIS}

Psoriatic arthritis (PsA) is a chronic inflammatory heterogeneous arthritis that is associated with psoriasis, and approximately $30 \%$ of patients with psoriasis develop PsA [1]. It is estimated that PsA has a prevalence rate of approximately 1-2 per 1000 in the general population and an incidence rate of approximately 6 per 100,000 per year [2, 3]. Generally, onset of PsA occurs between ages 30 and 50 years but can develop at any point throughout a patient's lifetime. The Group for Research and Assessment of Psoriasis and Psoriatic Arthritis (GRAPPA) defined six clinical domains that can be involved with PsA: peripheral arthritis, enthesitis, dactylitis, psoriasis, psoriatic nail disease, and axial disease [4-6].

Definitive diagnosis of PsA is further complicated by several arthritic conditions with similar clinical presentations. PsA is often undiagnosed and can be misdiagnosed for rheumatoid arthritis (RA) or osteoarthritis (OA), especially in a non-rheumatologic setting [7-9]. RA is a chronic inflammatory arthritis typified by pain, swelling, and stiffness of the joints, particularly symmetric small-joint synovitis of the hands and feet [10]. The lining of the joints is primarily affected in RA, and without adequate treatment, long-standing disease activity can result in permanent joint deformity and bone damage [11]. It is estimated that RA has global prevalence and incidence rates of 246.6 and 14.9 per 100,000 in the general population, respectively [12]. RA can present at any age, but peak age of onset is between ages 30 and 50 years, and likelihood increases with age [11]. $\mathrm{OA}$ is the most common non-inflammatory arthritic condition strongly associated with aging, and symptoms arise from deterioration of joint cartilage, which can cause changes in the bone and connective tissues of the joints [13]. Additionally, erosive inflammatory OA, typically affecting the hand, is a subset of OA that can mimic common inflammatory arthritic conditions, further complicating the distinction of OA from PsA [14, 15]; however, this subset of OA does not have an established diagnostic criterion [16], and therefore it will not be treated as a separate clinical condition throughout this review. Onset of OA is usually in the late 50s [7], affecting millions of people, with prevalence and incidence estimates varying depending on OA definition $[17,18]$. Recently, it was estimated that 242 million people were living with symptomatic and activity-limiting OA of the hip and/or knee globally [19].

A proper diagnosis and timely treatment of PsA are essential to prevent permanent joint damage and decrease functional disability 
$[20,21]$. Patients are often seen by various healthcare providers on their pathway to a diagnosis of PsA, including dermatologists, orthopedists, general practitioners, chiropractors, and advanced practice providers (APPs) [22]. Diagnosis of PsA relies on early detection through appropriate history taking, careful examination, and clinical judgment, and APPs are in a position to see many patients with different rheumatic diseases; therefore, it is imperative that APPs are aware of and receive proper training to accurately screen for features to identify PsA.

\section{STATEMENT OF LITERATURE SEARCH}

For the development of this narrative review, publications were identified by a series of searches on PubMed between September 2020 and July 2021. Search terms included "(diagnos* OR differentiat*) AND (psoriatic arthritis OR rheumatoid arthritis OR osteoarthritis)"; "(biomarker OR serologic* OR marker OR genetic*) AND (psoriatic arthritis OR rheumatoid arthritis OR osteoarthritis)"; "(IL-17 OR IL-12 OR IL-23, OR IL-6 OR TNF $\alpha$ OR IL-1 $\beta$ OR JAK/STAT) AND (psoriatic arthritis OR rheumatoid arthritis OR osteoarthritis)"; “(biologic* OR DMARD*) AND (psoriatic arthritis OR rheumatoid arthritis OR osteoarthritis)." Publications that detailed the characteristic clinical manifestations, comorbidities, pathogenesis, biomarkers, treatment recommendations, and differential diagnosis for PsA, RA, and OA were included. References that were determined to be irrelevant on the basis of the authors' judgment were excluded from consideration. Relevant references that were cited within the publications included in this review and articles previously known by authors were considered on the basis of the criteria. This review is based on studies that were previously completed and does not contain any novel studies with human participants that were conducted by any of the authors.

\section{KEY CLINICAL FEATURES FOR DIFFERENTIAL DIAGNOSIS OF PSA}

The similarities in clinical presentation of PsA and other rheumatic diseases can make a differential diagnosis challenging; therefore, it is crucial for APPs to be aware of characteristics and criteria indicative of a diagnosis of PsA. Clinical evaluation based on patient history and thorough physical examination can be supported by classification criteria to assist the practitioner in recognizing the combination of clinical features unique to PsA. The Classification for Psoriatic Arthritis criteria were developed from patient data to standardize enrollment in clinical trials of PsA; they have been shown to have high sensitivity and specificity for the diagnosis of PsA and have been incorporated into clinical settings to assist practitioners in the identification of potential signs of PsA [23]. These criteria require patients to present with at least one "stem" feature of inflammatory disease and at least three points given a numerical value to fulfill the PsA classification and could be included as part of a rheumatology referral checklist (Fig. 1).

Characteristic features that can assist in a differential diagnosis are enthesitis, dactylitis, uveitis, nail dystrophy with psoriasis, and articular involvement that can vary considerably and may involve the peripheral joints and axial spine (Fig. 2) [24, 25]. Enthesitis is more common in PsA than in other rheumatic conditions and affects $35-50 \%$ of patients with PsA [26]. Enthesitis can present before arthritis symptoms in patients with PsA and may be the only musculoskeletal manifestation in early PsA; thus, imaging can be helpful to identify patients with subclinical disease when other clinical symptoms are absent [24]. The most frequent areas of enthesitis are the insertion sites of the plantar fascia, Achilles tendon, lateral epicondyle of the elbow, and ligament attachments at the knee [27]. Dactylitis ("sausage" fingers or toes) is the uniform swelling of the digits due to inflammation and affects up to $50 \%$ of patients with PsA [28]. The hands and feet should be carefully examined for signs of 
$\square$ Current/prior medications

$\square$ Imaging

$\square$ Fluid samples and findings

$\square$ Biomarkers

$\square$ RF
$\square$ CCP
$\square$ ESR
$\square$ CRP
$\square$ HLA-B27
$\square$ Uric acid (gout)
Morning stiffness
$\square$ Improves with movement
$\square>1$ hour

$\square$ Disease domains involved

$\square$ Peripheral arthritis

$\square$ Axial disease

$\square$ Dactylitis

$\square$ Enthesitis

$\square$ Nail disease

$\square$ Psoriatic skin disease

\section{CASPAR}

Stem feature ( $\geq 1$ fulfills criteria)

$\square$ Peripheral arthritis

$\square$ Enthesitis

$\square$ Axial disease

Disease manifestations with numerical values ( $\geq 3$ fulfill criteria)

$\square$ Personal and/or family history of psoriasis (1 point)

$\square$ Current psoriasis (2 points)

$\square$ Psoriatic nail dystrophy (1 point)

RF-negative status (1 point)

$\square$ Current/history of dactylitis (1 point)

$\square$ Juxta-articular new bone formation (1 point)

Mark joints involved

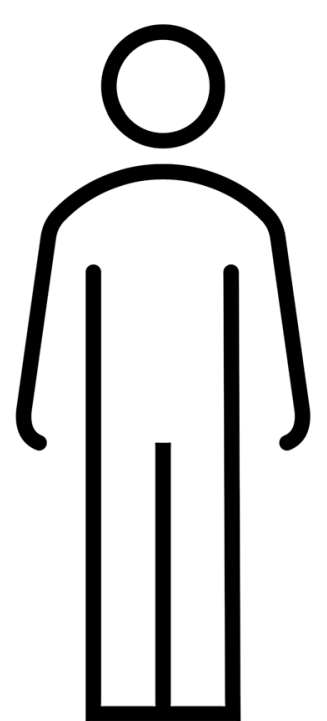

Fig. 1 Suggested rheumatology referral checklist. CASPAR Classification for Psoriatic Arthritis, CCP cyclic citrullinated peptide, CRP C-reactive protein, ESR erythrocyte sedimentation rate, RF rheumatoid factor

dactylitis, which often presents as diffuse digit swelling of a finger or toe accompanied by redness of the skin, and pain [29]. Dactylitis can be an indicator of disease severity; affected digits have been found to have significantly greater joint damage compared with non-affected digits in patients with early PsA [30, 31].

Furthermore, the common association between PsA and psoriasis is well established. Patients with psoriasis can be screened for PsA in routine clinical settings to prevent diagnostic 


\section{Osteoarthritis}

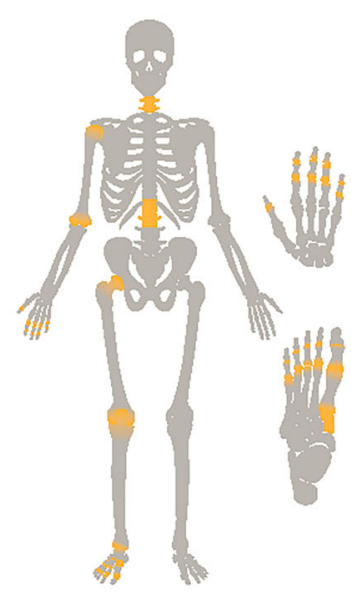

Stiffness with activity

Sclerosis

Bone spurs

Joint space narrowing
Psoriatic Arthritis

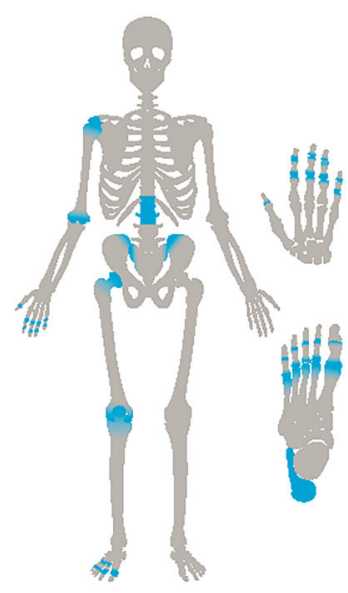

Psoriasis

Nail dystrophy

Sacroiliitis

Ankylosis

Dactylitis

Enthesitis

\section{Rheumatoid Arthritis}

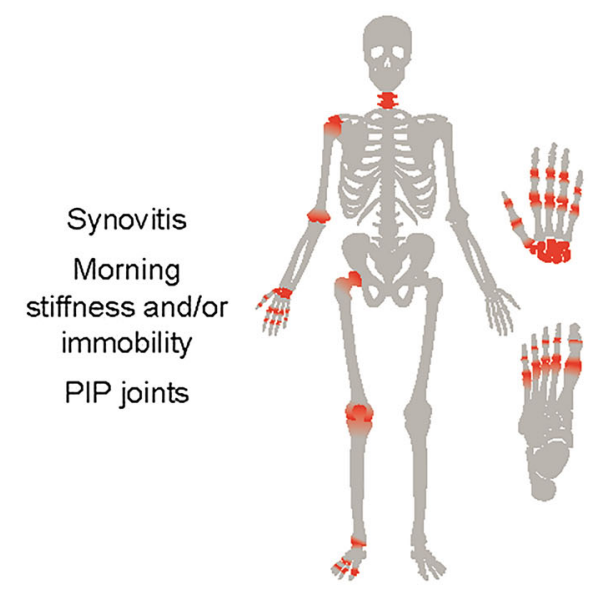

Symmetric peripheral disease

Bone erosion

Proximal involvement

Destructive bone lesions

Fig. 2 Clinical manifestations characteristic of psoriatic arthritis to differentiate from characteristics of osteoarthritis and rheumatoid arthritis. DIP distal interphalangeal, PIP proximal interphalangeal

\section{A Nail matrix psoriasis}

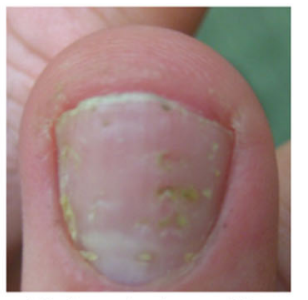

Pitting, leukonychia

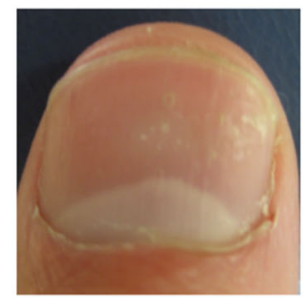

Leukonychia

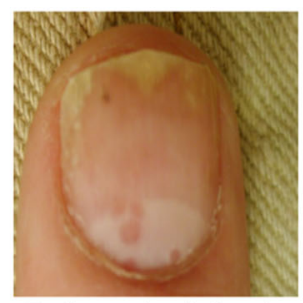

Red macules in lunula

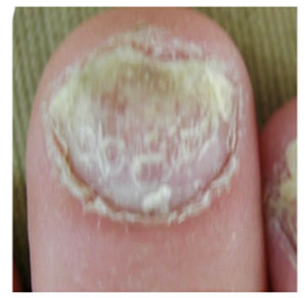

Crumbling

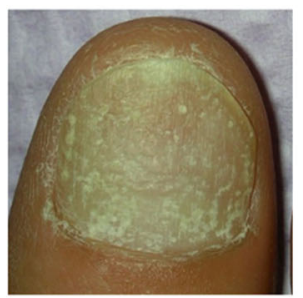

Trachyonychia

\section{B Nail bed psoriasis}

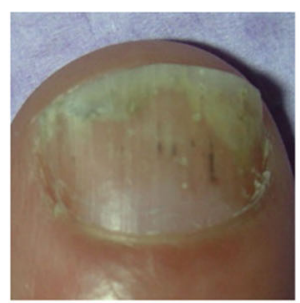

Splinter hemorrhages and onycholysis

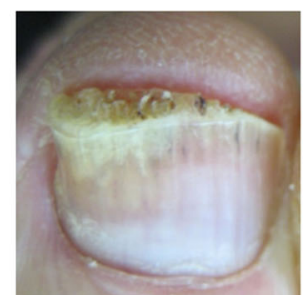

Hyperkeratosis and splinter hemorrhages

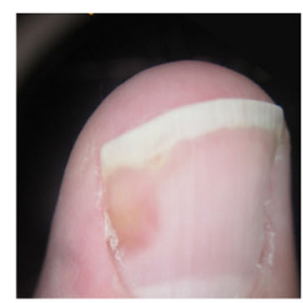

Salmon patch or oil spot dyschromia

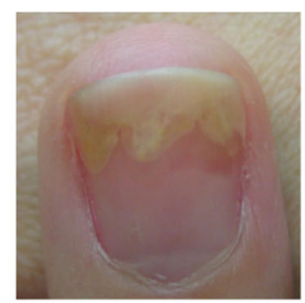

Onycholysis and salmon patch dyschromia

Fig. 3 Examples of characteristic psoriatic (a) nail matrix and (b) nail bed presentations (image reprinted from Kaeley GS, et al. J Rheumatol. 2021;48(8):1208-20. https://doi.org/10.3899/jrheum.201471 [37]) 
delays; in the majority of patients (75-80\%), psoriatic skin involvement precedes presentation of peripheral involvement, with approximately 7-12 years between onset of psoriasis and diagnosis of PsA [25, 32, 33]. Additionally, the degree of severity, the amount of body area affected, and the areas of the body (e.g., scalp and nails) affected by psoriasis can increase the risk of developing PsA [34, 35]. Psoriatic nail lesions can be important in differential diagnosis, occurring in over $60 \%$ of patients with PsA, but uncommonly in RA and OA [36]. Changes that involve the nail matrix are characterized by pitting, leukonychia (i.e., white discoloration), nail plate crumbling, red spots on the lunula, and trachyonychia (Fig. 3) [37]. When the nail bed is affected, symptoms include salmon patch or oil spots, onycholysis, subungual hyperkeratosis, and splinter hemorrhages [38, 39]. Each nail lesion arises from different processes in the nail complex, and progression of entheseal inflammation in the distal interphalangeal extensor tendon of the nail is believed to be the cause of psoriatic nail changes seen in patients with PsA [40]. Comorbid psoriasis can help substantiate a definitive diagnosis of PsA, although the presence of psoriasis alone is not sufficient to differentiate this disease, as psoriasis has been reported in RA and OA [41-43]

Distinctive features of joint involvement in PsA, particularly in an early disease state, include inflammatory asymmetric monoarticular to oligoarticular distribution, possible spondylitis including sacroiliitis, and distal small-joint inflammation in the hands and feet. These elements can help discern PsA from RA, as the presentation seen with RA includes symmetric and polyarticular distribution, proximal hand and foot involvement, more tender and swollen joints, and the absence of sacroiliitis $[20,26,44]$. Conversely, OA can present with joint involvement similar to that of PsA; however, it is non-inflammatory in nature compared with PsA and RA. Morning stiffness and/ or worsening joint stiffness with inactivity is common in patients with PsA and RA, whereas joint pain and stiffness associated with OA tends to be exacerbated with activity and improves with rest [45]. While involvement of distal interphalangeal joints is common in both PsA and OA, distal interphalangeal involvement in PsA is frequently associated with psoriatic nail disease and joint inflammation, compared with related bone spurs in OA $[24,46]$.

It is also important to distinguish between the two major arthritis patterns in patients with suspected PsA-peripheral and/or axial-since the type of arthritis can impact patient disease state and treatment strategy. The majority of patients with PsA experience peripheral joint involvement, and approximately $25-70 \%$ of patients have axial involvement [47, 48], depending on the definition of axial disease applied. To screen for peripheral arthritis, practitioners should evaluate patients for swelling and tenderness, which can be indicative of synovitis and inflammation, as well as commonly affected joints, such as feet and hands, knees, wrists, ankles, and shoulders [24]. Axial arthritis can be an indicator of higher disease severity [49] and commonly presents with slowly developing inflammatory back pain (IBP) [50-52]. IBP is defined by the Assessment of SpondyloArthritis international Society as chronic back pain for at least 3 months, with onset before the age of 40 years, pain that causes waking during sleep, and stiffness that improves with activity [53-55]. Since patients present with back pain in general medicine settings for a variety of reasons [56], it is important to distinguish IBP from mechanical back pain, the latter of which is an injury or structural abnormality in the lower back [50, 57]. Axial PsA is associated with a particularly high incidence of sacroiliitis, which can present as bilateral and symmetric, based on genetic status (HLA-B27). HLA-B27-positive status has been linked to increased inflammatory involvement in the sacroiliac joint and lumbar spine, compared with more involvement in the cervical spine seen in patients with HLA-B27-negative status $[58,59]$. An early manifestation of axial involvement associated with PsA is the formation of asymmetric syndesmophytes and paraspinal ossifications $[60,61]$. The presence of spondylitis and sacroiliitis can be detected in the axial skeleton using highly sensitive imaging modalities, such as the identification of 
characteristic bone marrow edema on magnetic resonance imaging (MRI).

The presence of comorbidities has been linked to each arthritic condition discussed here, yet differences among patient comorbidities may help distinguish PsA from RA or OA. Some comorbidities are significantly more common among patients with PsA, including inflammatory conditions, such as ulcerative colitis (1.1-1.28\%), Crohn's disease (1.0-1.13\%), and uveitis (7.0-25.1\%), and other metabolic conditions such as obesity (6.0-45.0\%) and diabetes mellitus (6.1-20.2\%) [62-64]. Of note, patients with PsA or RA have comparable increased risk of cardiovascular disease (CVD) compared with the general population; in a real-world observational study, $10.3 \%$ and $12.3 \%$ of patients with RA or PsA, respectively, reported CVD [65-67]. Comorbidities in patients with OA have been found to be similar to those with PsA, especially obesity, metabolic syndrome, and CVD [68-72], but practitioners can still screen for psoriasis and uveitis to contribute to a definitive diagnosis of PsA vs OA.

\section{APPLICATION OF IMAGING MODALITIES FOR DIFFERENTIAL DIAGNOSIS OF PSA}

The use of conventional radiographs and more modern imaging modalities, such as ultrasonography (US), MRI, and computed tomography, can provide essential information to aid practitioners in the diagnosis, prognosis, and monitoring of treatment response in PsA. Imaging modalities can also aid in detecting subclinical joint and/or entheseal inflammation and/or morphological changes that may be present in patients with PsA who may not meet the Classification for Psoriatic Arthritis criteria for identification of PsA. The appropriate use of imaging techniques is essential for the accurate assessment of joint and bone damage to facilitate intervention with suitable therapy.

Traditional radiography can be particularly effective to detect and monitor the structural damage seen in PsA. In the evaluation of patients with suspected PsA, structural changes are likely seen in the hands and feet, although other joints can be involved [73, 74]. Common radiographic changes to screen for include periostitis and new bone formation with concurrent joint damage characterized by erosions and joint space narrowing, osteolysis, subluxation, bone ankylosis, and pencil-in-cup change (Fig. 4) $[75,76]$. Plain radiography can help visualize the joints of the spine, including the sacroiliac joints, and entheseal new bone formation; however, these changes are more common in late-stage PsA [77, 78]. Radiographs can be used to discern suspected PsA from OA and RA (Fig. 2). Cartilage loss from OA appears as joint space narrowing with occasional sclerosis and can be diffuse, whereas changes from inflammatory arthritis are more discrete. RA can present with erosive changes on the periphery of the joint, and PsA is distinguished by proliferative findings [79]. Although radiography can be useful since it can penetrate bone surface and visualize certain aspects of structural changes, it has restricted utility in imaging the soft-tissue changes seen in early stages of PsA [31, 80]. Importantly, radiographs can appear normal at early stages of PsA, which can cause misdiagnosis and/or delays in diagnosis if other imaging modalities are not applied.

US imaging is a useful tool that rheumatologists can use to help visualize inflammatory alterations in soft tissues, such as the synovium, tendons, and entheses, as well as superficial structural changes on the bone surface characteristic of PsA [81, 82]. Synovitis in PsA is nonspecific on US imaging but can pinpoint joint involvement, and a scoring system has been established by the Outcome Measures in Rheumatology (OMERACT) US Working Group to evaluate the degree of synovitis [83]. US can support the early detection and prognosis of subclinical synovitis, and increased US detection of PsA has been reported compared with clinical examination, which can be used to prevent misdiagnosis $[84,85]$. US is commonly used to visualize enthesitis and has been reported to be superior to clinical examination for the detection of enthesitis in the lower limbs of patients with spondyloarthritis [77, 86, 87]; the OMERACT US Task Force reached a consensus on the sonographic lesions that define 
A

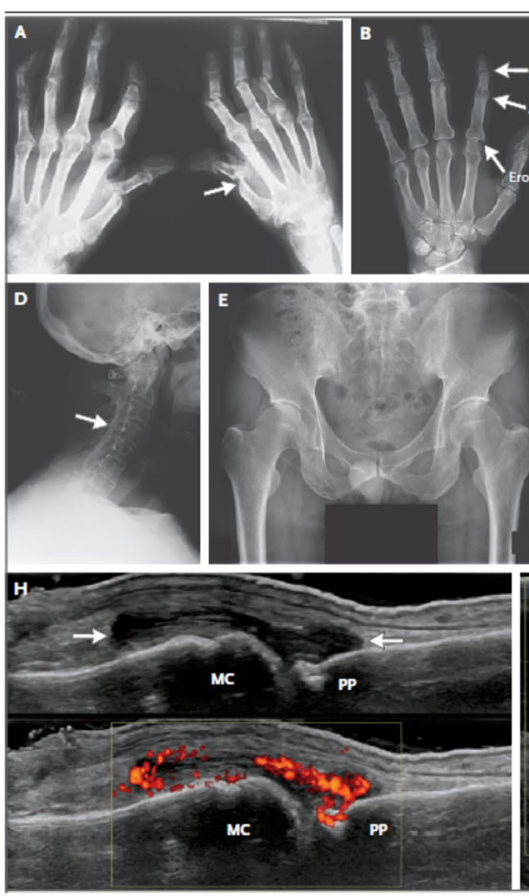

Fig. 4 Characteristic radiographic features in PsA. Images from A Ritchlin CT, et al. $N$ Engl $J$ Med. 2017;376(10):957-70. htps://doi.org/10.1056/ NEJMra1505557 and B Braga MV, et al. Sci Rep. 2020;10(1):11580. https://doi.org/10.1038/s41598-020$68456-7^{\mathrm{b}}$. MC metacarpal head, MRI magnetic resonance imaging, PP proximal phalanx, STIR short-tau inversion recovery. ${ }^{a}$ Radiographic features of PsA: a arthritis mutilans, with pencil-in-cup deformities (arrow) and marked bone resorption (osteolysis) in phalanges of the right hand; $\mathbf{b}$ the hand radiograph shows joint resorption, ankylosis, and erosion in a single ray; $\mathbf{c}$ enthesophytes at the plantar fascia and Achilles' tendon insertions; and $\mathbf{d}$ syndesmophytes involving the cervical spine, with ankylosis of facet joints (arrow); e bilateral grade 3 sacroiliitis; f paramarginal syndesmophyte bridging the fourth and fifth lumbar vertebrae; $\mathbf{g}$ bone marrow edema

spondyloarthritis-related enthesitis, and the GRAPPA US Working Group developed an US enthesitis score for PsA [88]. Enthesitis in PsA is typified by five abnormalities: tendon thickening and hypoechogenicity, erosions, enthesophytes, calcifications, and abnormal blood flow detected by power Doppler signal at the entheses, all of which can be visualized via US imaging [89]. Additionally, US imaging is the
B

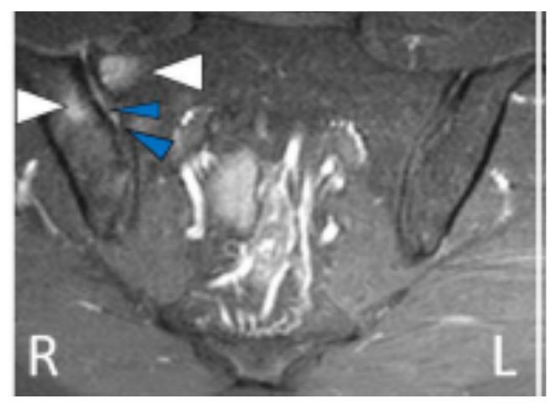

in the second and third lumbar vertebrae in a patient with severe psoriasis and new onset of back pain; $\mathbf{h}$ high-frequency $(15 \mathrm{MHz})$ grayscale ultrasound image shows synovitis of the metacarpophalangeal joint. Distention of the joint capsule is evident (arrows). The confluent red signals (box in the lower part of the image) with power Doppler ultrasonography indicate synovial hyperemia; and $\mathbf{i}$ highfrequency $(15 \mathrm{MHz})$ ultrasound image shows enthesitis. The confluent red signals with power Doppler ultrasonography represent hyperemia at the tendon near its insertion into the calcaneus. Normally, the tendon is poorly vascularized [76]. ${ }^{\mathrm{b}}$ Unilateral acute sacroiliitis of the sacroiliac joints that can be seen on MRI. Coronal STIR sequence: high signal intensities on the right compatible with bone marrow edema (white arrows) and enthesitis (blue arrows)[75]

preferred method for imaging components of dactylitis to identify the characteristic flexor tenosynovitis and increased subcutaneous softtissue swelling, particularly in early disease [90, 91].

The high sensitivity of MRI can be used for the early detection of active inflammatory responses that can be seen in early PsA, and the OMERACT MRI in Arthritis Working Group has 
developed definitions for pathologies commonly seen in PsA [92]. The detailed MRI findings common in PsA include thickening of tendons and ligaments, joint effusions and inflammation, bone erosions, enthesophytes, and bone marrow edema [93, 94]. Structural abnormalities often seen in patients with PsA, such as the localization of bone marrow edema in proximity to enthesitis, soft-tissue inflammation and tendon involvement [95], and location of erosions, can be applied as distinguishing factors visible with MRI $[96,97]$. More specifically, APPs can note the location of bone marrow edema, which is near the entheses in PsA compared with the capsular attachments in $\mathrm{RA}$, and areas of tenosynovitis are soft-tissue inflammation around the tendon sheath related to dactylitis as opposed to in the hands and wrists in RA [95, 98]. However, small studies reported overlap of MRI findings in PsA and OA, such as bone marrow edema, synovitis, and periostitis, which can add to the challenge of a differential diagnosis [7, 96, 99]. Additionally, for patients with disease that has progressed, the fat deposition and erosions characteristic of chronic inflammation can be visualized with MRI. Features of enthesitis and dactylitis can be visualized with MRI; however, detection in peripheral joints can be difficult because of the potential for low signal in areas with low water accumulation, such as bone attachments $[31,100]$. MRI is the preferred first-line modality for patients with suspected axial PsA who are younger and/or who have shorter disease duration [101]. Active inflammation (i.e., synovitis and enthesitis) at the sacroiliac joints and bone marrow edema throughout the entire spine, for patients who may have more cervical involvement, can be evaluated via MRI; this is important as early detection prevents irreversible damage on plain film [97, 101].

Computed tomography can illustrate the structural damage (i.e., bone erosion, sclerosis, joint space alterations) associated with axial involvement in PsA with high resolution; however, it is not recommended or widely used in routine clinical practice unless radiography is negative and the use of MRI is not possible.

Although each imaging modality has its advantages and limitations, imaging can be valuable for the differential diagnosis of PsA, the assessment of disease severity, monitoring of structural and inflammatory changes, and gauging treatment efficacy.

\section{BIOMARKERS THAT CAN FACILITATE DIFFERENTIATION OF PSA, RA, AND OA}

One challenge in the diagnosis of PsA is the lack of validated biomarkers detectable in the serum or synovial fluid that are unique to PsA; however, there are serologic, genetic, and inflammatory markers that can be screened to substantiate clinical findings.

Serologic analyses for rheumatoid factor (RF) and cyclic citrullinated peptide (CCP) can be used to facilitate the distinction between PsA and RA. Approximately $80 \%$ of patients with RA are RF positive and CCP positive, while nearly all patients with PsA are RF and/or CCP negative [102]. However, it is important to not rule out PsA solely on the basis of CCP- and/or RF-negative status, as an estimated $13 \%$ of patients with PsA are RF positive [33]. Additionally, C-reactive protein (CRP) and erythrocyte sedimentation rate (ESR) have been shown to be markers of inflammation in patients with RA and PsA. Both ESR and CRP were reported to significantly predict radiographic progression in RA [8]. Patients with PsA, on average, have lower ESR and CRP levels than patients with RA, yet elevations of both have been significantly correlated with the number of swollen joints, structural damage, and abnormalities detected with US [84, 103]. Elevated ESR and CRP levels that are attributed to PsA are considered markers of severe PsA by the American College of Rheumatology (ACR)/National Psoriasis Foundation, and tumor necrosis factor inhibitors (TNFis) and/or anti-interleukin-17 (IL-17) biologic disease-modifying antirheumatic drugs (bDMARDs) are recommended for earlier use in these patients [3, 104, 105].

Genetic factors can also assist in differential diagnosis of PsA; HLA-B27, in particular, has been linked to the increased susceptibility to develop PsA among patients with psoriasis, which can also be affected by family history 
and/or race [106, 107]. HLA-B27 has also been linked to development of enthesitis and symmetric sacroiliitis and is more common among patients with axial involvement than those without [108, 109]. Among patients with RA who are RF and CCP positive, the presence of HLA-DRB1 alleles has been associated with disease severity and susceptibility to develop RA [110]; this genetic factor is generally absent in patients with PsA but has been associated as a risk factor for inflammatory bowel disease and may indicate the presence of inflammatory bowel disease among patients diagnosed with PsA [111]. While the presence of HLA-B27 or HLA-DRB1 alone would not constitute a definitive diagnosis, it can be used to substantiate a diagnosis along with clinical signs and symptoms.

\section{TREATMENT RECOMMENDATIONS AND GUIDELINES FOR MANAGEMENT OF PSA}

Once a confirmed diagnosis of PsA is established, providers can utilize known inflammatory markers to facilitate determination of the optimal treatment strategy for patients. Inflammatory responses in arthritic diseases result in increased production of pro-inflammatory cytokines that act together to propagate chronic inflammation (Table 1). TNFa overexpression has been linked to the pathogenesis of PsA, RA, and OA [112-114]. IL-17 is increased in the synovial fluid and psoriatic plaques of patients with PsA [115-118]. Cytokines IL-12 and IL-23 also have established roles in the pathogenesis of PsA [119-123]. Additionally, IL6 dysregulation plays a key role in the development and progression of RA [124-126] and has been associated with age-related inflammation and radiographic knee OA [127], and increased IL-6 levels are seen in the synovium in PsA $[114,128]$. IL-1 $\beta$ plays a crucial role in the pathogenesis of OA [129-131]. However, elevated levels of IL-1 $\beta$ are also frequently seen in PsA and RA [132], so this dysregulation alone cannot be used to differentiate diagnosis. High numbers of activated $\mathrm{T}$ cells are found in the inflamed joints and skin of patients with PsA and have also been linked to the pathogenesis and progression of RA [133-135]. Lastly, the role of the Janus kinase (JAK)/signal transducer and activator of transcription (STAT) pathway is implicated in the pathogenesis of these diseases [136-140]. Several cytokines that are upregulated in RA and/or PsA can promote increased cytokine release through several JAK/STAT pathways, potentiating further inflammatory responses that can propagate cycles of chronic inflammation [137, 141]. Overlap in intracellular signaling cascades that are involved in the pathogenesis of each disease can add to the challenge of differentiating PsA from RA and $\mathrm{OA}$; however, assessment of each of these markers may be part of a clinical examination to substantiate clinical presentation and could be used to determine optimal treatment plans.

Early treatment intervention of PsA has the potential to significantly impede disease progression and allow patients to maintain quality of life. Patients are often seen by several healthcare providers (e.g., primary care providers, dermatologists, orthopedists) along their journey to a definitive diagnosis. One study reported that among those surveyed, patients with PsA were most commonly treated by a general practitioner (79.8\%), rheumatologist (66.5\%), dermatologist (33.0\%), and/or orthopedist $(21.7 \%)$ and found that patients with increased time to diagnosis were significantly more likely to have initially sought care from general practitioners, orthopedists, and chiropractors [22]. Upon appropriate identification of suspected PsA, a referral to a rheumatologist should follow, and a comprehensive referral is crucial to best assist in the diagnosis of PsA and choice of an appropriate treatment strategy. We recommend that patient history, imaging, laboratory tests, history of joint involvement, synovial fluid draining and findings (e.g., cell count, crystal deposits, and cultures), and the disease domains involved be included in a referral (Fig. 1). A study that included data for 405 newly diagnosed patients with PsA included in the Dutch south-west Early Psoriatic Arthritis cohort found diverse primary manifestations at time of diagnosis, with domain presentation ranges from $12.6 \%$ to $85 \%$ [142]. Furthermore, in a study among 2617 patients 
Table 1 Pro-inflammatory cytokines associated with disease pathogenesis of PsA, RA, and OA

\begin{tabular}{|c|c|c|c|}
\hline Cytokine & Description & Cell signaling regulation & Targeted therapies \\
\hline $\begin{array}{l}\mathrm{TNF} \alpha \\
{[112-114]}\end{array}$ & $\begin{array}{l}\text { Inflammatory cytokine produced } \\
\text { by Th1, Th22, Th17, NK, and } \\
\text { dendritic cells, as well as } \\
\text { macrophages and neutrophils }\end{array}$ & $\begin{array}{l}\text { Overexpression linked to } \\
\text { pathogenesis of PsA, RA, and } \\
\text { OA }\end{array}$ & $\begin{array}{l}\text { TNFis approved and } \\
\text { recommended for PsA and RA } \\
\text { include etanercept, infliximab, } \\
\text { adalimumab, golimumab, and } \\
\text { certolizumab pegol }\end{array}$ \\
\hline $\begin{array}{l}\text { IL-17 } \\
\qquad[115-118]\end{array}$ & $\begin{array}{l}\text { Inflammatory cytokine produced } \\
\text { by Th17, Th9, innate lymphoid, } \\
\text { and mast cells, as well as } \\
\text { neutrophils }\end{array}$ & $\begin{array}{l}\text { Increased in the synovial fluid and } \\
\text { psoriatic plaques of patients with } \\
\text { PsA } \\
\text { Associated with pathogenesis of } \\
\text { PsA but not established for RA or } \\
\text { OA }\end{array}$ & $\begin{array}{l}\text { IL-17is approved and } \\
\text { recommended for PsA include } \\
\text { secukinumab and ixekizumab }\end{array}$ \\
\hline $\begin{array}{l}\text { IL-12/23 } \\
\text { and IL-23 } \\
{[119-123]}\end{array}$ & $\begin{array}{l}\text { Pro-inflammatory cytokines } \\
\text { produced by dendritic cells and } \\
\text { macrophages }\end{array}$ & $\begin{array}{l}\text { IL-12 stimulates Th1 cells } \\
\text { IL- } 23 \text { regulates Th17 cells at sites } \\
\text { of enthesitis }\end{array}$ & $\begin{array}{l}\text { IL-12/23i and IL-23i approved } \\
\text { and recommended for PsA are } \\
\text { ustekinumab and guselkumab, } \\
\text { respectively }\end{array}$ \\
\hline $\begin{array}{l}\text { IL-6 } \\
\qquad[124-128]\end{array}$ & $\begin{array}{l}\text { Produced by dendritic cells, } \\
\text { macrophages, and neutrophils }\end{array}$ & $\begin{array}{l}\text { Elevated levels of IL-6 have been } \\
\text { reported in the synovial fluid of } \\
\text { patients with RA and PsA and } \\
\text { the serum and plasma in patients } \\
\text { with RA } \\
\text { Plays a role in RA progression via } \\
\mathrm{T} \text { and B cell activation, } \\
\text { autoantibody and acute-phase } \\
\text { protein production, and } \\
\text { osteoclast and synoviocyte } \\
\text { stimulation } \\
\text { Increased IL-6 levels have been } \\
\text { associated with age-related } \\
\text { inflammation and are predictive } \\
\text { of radiographic knee OA }\end{array}$ & $\begin{array}{l}\text { IL-6 receptor antagonists } \\
\text { approved and recommended } \\
\text { for RA include tocilizumab } \\
\text { and sarilumab }\end{array}$ \\
\hline $\begin{array}{l}\text { IL-1 } \beta \\
\qquad[129-132]\end{array}$ & $\begin{array}{l}\text { Produced by macrophages and } \\
\text { neutrophils in the joint and } \\
\text { synovial membrane }\end{array}$ & $\begin{array}{l}\text { Shown to induce inflammation and } \\
\text { catabolic effects of the articular } \\
\text { cartilage and other aspects of } \\
\text { joints leading to OA } \\
\text { Elevated levels are also seen in } \\
\text { patients with PsA and RA }\end{array}$ & $\begin{array}{l}\text { IL-1 receptor antagonist } \\
\text { approved for RA is anakinra }\end{array}$ \\
\hline
\end{tabular}


Table 1 continued

\begin{tabular}{|c|c|c|c|}
\hline Cytokine & Description & Cell signaling regulation & Targeted therapies \\
\hline $\begin{array}{l}\text { T cells } \\
\quad[133-135]\end{array}$ & $\begin{array}{l}\text { A type of white blood cell that is } \\
\text { key to the function and } \\
\text { regulation of the immune system } \\
\text { to protect the body from } \\
\text { infection }\end{array}$ & $\begin{array}{l}\text { An increased number of activated } \\
\mathrm{T} \text { cells, including Th17 cells, are } \\
\text { found in the inflamed joints and } \\
\text { skin of patients with PsA } \\
\text { Aberrant regulation and function } \\
\text { of Th and Treg cells have been } \\
\text { linked to the pathogenesis and } \\
\text { progression of RA }\end{array}$ & $\begin{array}{l}\text { A T cell co-stimulation } \\
\text { modulator approved for RA } \\
\text { and PsA is abatacept }\end{array}$ \\
\hline $\begin{array}{l}\text { JAK/STAT } \\
\text { [136-139] }\end{array}$ & $\begin{array}{l}\text { Pro-inflammatory cytokines signal } \\
\text { through and regulate the JAK/ } \\
\text { STAT pathways }\end{array}$ & $\begin{array}{l}\text { Several pro-inflammatory cytokines } \\
\text { recruit and activate immune cells } \\
\text { to sites of inflammation and } \\
\text { increase cytokine regulation } \\
\text { through JAK/STAT pathways }\end{array}$ & $\begin{array}{l}\text { JAK inhibitor approved for PsA } \\
\text { and RA is tofacitinib } \\
\text { JAK inhibitors approved for RA } \\
\text { include baricitinib and } \\
\text { upadacitinib }\end{array}$ \\
\hline
\end{tabular}

$I L-12 / 23 i$ interleukin-12/23 inhibitor, $I L-17 i$ interleukin-17 inhibitor, $I L-23 i$ interleukin-23 inhibitor, JAK Janus kinase, $N K$ natural killer, $O A$ osteoarthritis, $P S A$ psoriatic arthritis, $R A$ rheumatoid arthritis, $S T A T$ signal transducer and activator of transcription, $T h$ helper $\mathrm{T}$ cell, $T N F i$ tumor necrosis factor inhibitor, Treg regulatory $\mathrm{T}$ cell

with established PsA [mean (SD) disease duration of 8.5 (8.1) years] enrolled in a registry, domain presentation and comorbidities were varied; individual domain presentation ranged from $9.0 \%$ to $69.3 \%$, and common comorbidities included uveitis $(0.9 \%)$, Crohn's disease (1.0\%), and ulcerative colitis (0.9\%) (Fig. 5) [143]. It is important for APPs to make note of the disease domain type and severity involved since it may impact treatment options and effectiveness.

The care and management of PsA relies primarily on pharmacological measures, and the appropriate choice is vital to optimize treatment response. There is overlap in approved treatment options for PsA, RA, and OA (Table 2) [3, 105, 144-149]; therefore, a definitive diagnosis of PsA is paramount for the appropriate choice to optimize therapeutic response. Different classes of DMARDs are indicated for PsA and RA, including conventional synthetic (csDMARDs), biologic (bDMARDs), and targeted synthetic (tsDMARDs) [105, 146]; however, none of these are approved for OA. csDMARDs, along with nonsteroidal anti-inflammatory drugs (NSAIDs) and glucocorticoids, are widely used as initial treatment for the signs and symptoms of PsA and RA, and NSAIDs are used for patients with OA. The overlap of approved csDMARDs for PsA and RA include methotrexate and leflunomide, while there are a number of other csDMARDs indicated for RA but not PsA [9]. The majority of bDMARDs have been widely recognized for their ability to effectively improve signs and symptoms and inhibit the structural progression seen with PsA and RA, although targeting IL-12/23 and IL-23 has not been reported to inhibit structural progression; there are inconclusive and limited data on the use of bDMARDs in OA $[105,150]$. TNFis are approved for active PsA and RA and have been widely established as an effective bDMARD for these patients. More selective novel bDMARDs have been developed with different mechanisms of action linked to PsA and RA, including those that target IL-17 [151, 152], IL-12/23 [153-156], and IL-23 [157, 158] in PsA; IL-1 [159, 160], CD20 [161], and IL-6 [162] in RA; and $\mathrm{T}$ cell modulation in both RA and PsA $[163,164]$. More recently, tsDMARDs that 
A

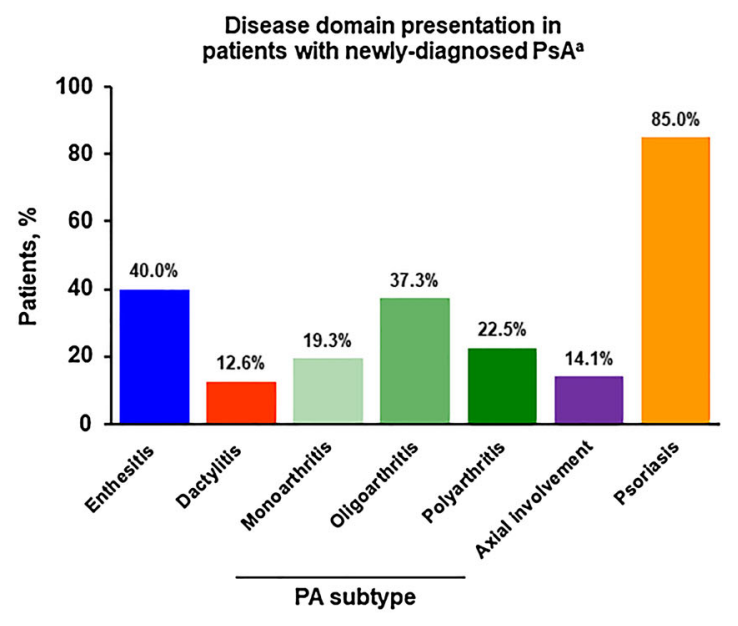

Fig. 5 Frequency of disease domains in patients with PsA. ASAS Assessment of SpondyloArthritis international Society, CBP chronic back pain, CD Crohn's disease, CVD cardiovascular disease, IBP inflammatory back pain, LDI Leeds Dactylitis Index, LEI Leeds Enthesitis Index, PA peripheral arthritis, PASI Psoriasis Area and Severity Index, PsA psoriatic arthritis, SPARCC Spondyloarthritis Research Consortium of Canada, SJC swollen joint count, TJC tender joint count, UC ulcerative colitis, VAS visual analog scale. ${ }^{a}$ Disease domains were defined as follows: (1) enthesitis: patients with LEI $>0$; (2) dactylitis: determined by LDI $>0$; (3) PA: disease subtype was determined at diagnosis by rheumatologist and defined by primary presentation as monoarthritis (1 joint), oligoarthritis (2-4 joints), and polyarthritis ( $\geq 5$ joints); (4) axial involvement: patients were classified as having CBP if they reported chronic complaints of back pain for a duration of longer than 3 months at present or in the past 12 months and with onset $<45$ years of age. Of these

specifically target JAK/STAT and phosphodiesterase 4 (PDE4) have been approved in PsA and RA owing to the growing evidence of the dysregulation of these pathways in both diseases, although more tsDMARDs are approved for RA than PsA [165-167]. Given the overlap in treatment options for PsA, RA, and OA, a differential diagnosis is imperative prior to treatment initiation as variations in inflammatory responses and patient demographics may arise from different mechanisms of action, which should be considered for the development of an appropriate treatment plan.
B

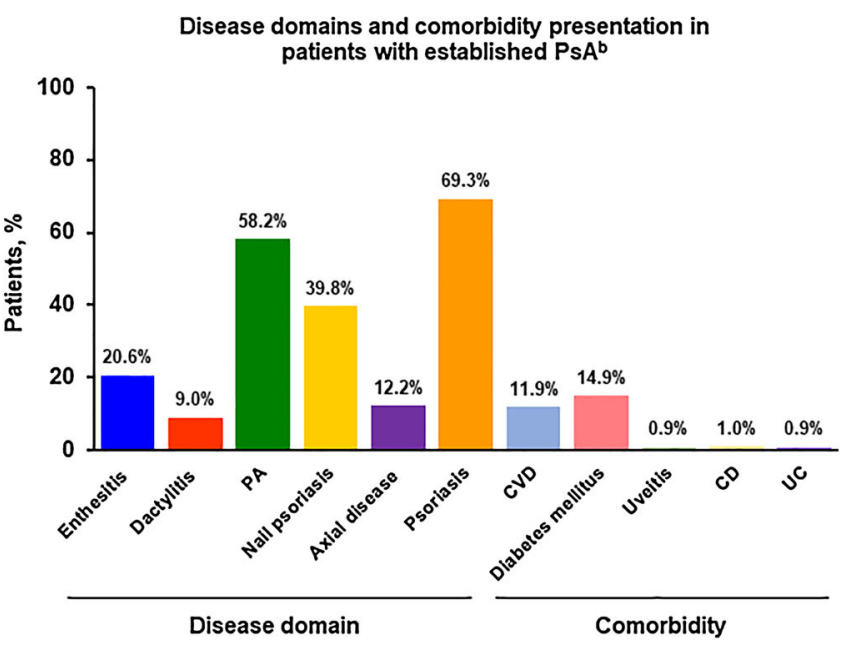

patients, fulfillment of the ASAS classification criteria for IBP was determined; (5) psoriasis: patients with PASI $>1$ [142]. ${ }^{b}$ Disease domains were defined as follows: (1) enthesitis: patients with SPARCC $>1$; (2) dactylitis: patients with peripheral dactylitis $>1$; (3) PA: patients with TJC and/or SJC > 0; (4) nail psoriasis: patients with global nail psoriasis severity VAS $>0$; (5) axial disease: patients with physician-reported presence of spinal involvement at time of registry enrollment, based on clinical judgment of features thought to be representative of active inflammatory spondylitis and/or radiographs or magnetic resonance imaging (MRI) showing sacroiliitis such as sacroiliitis grade $>2$ bilaterally or grades 3-4 unilaterally by $\mathrm{x}$-ray, active (acute) inflammation on MRI highly suggestive of sacroiliitis associated with $\mathrm{SpA}$, definite radiographic sacroiliitis according to modified New York criteria, and other evidence of sacroiliitis on imaging; and (6) skin disease: patients with $>0 \%$ body surface area affected by psoriasis

Guidelines and treatment recommendations present healthcare providers with the best evidence available for circumstances commonly seen in patients to allow practitioners to deliver optimal care. Recommendations and guidelines for the treatment of PsA have been developed by the European League Against Rheumatism, GRAPPA, and ACR/National Psoriasis Foundation, which broadly propose an escalation-type approach to therapy and can be managed and initiated by rheumatology providers following an appropriate referral $[3,105,144]$. Similar 
Table 2 FDA-approved therapies for PsA, RA, and OA

\begin{tabular}{|c|c|c|c|}
\hline Class & PsA $[3,105,144]$ & $\mathrm{RA}[145,146]$ & OA [147-149] \\
\hline csDMARDs & $\begin{array}{l}\text { MTX, leflunomide, } \\
\text { sulfasalazine, cyclosporine }\end{array}$ & $\begin{array}{l}\text { MTX, leflunomide, sulfasalazine, } \\
\text { hydroxychloroquine, cyclosporine }\end{array}$ & \\
\hline \multirow[t]{6}{*}{ bDMARDs } & $\begin{array}{l}\text { TNFis: etanercept, infliximab, } \\
\text { adalimumab, golimumab, } \\
\text { certolizumab pegol }\end{array}$ & $\begin{array}{l}\text { TNFis: etanercept, infliximab, } \\
\text { adalimumab, golimumab, } \\
\text { certolizumab pegol }\end{array}$ & \\
\hline & $\begin{array}{l}\text { IL-17 inhibitors: secukinumab, } \\
\text { ixekizumab }\end{array}$ & $\begin{array}{l}\text { IL-6 receptor antagonists: tocilizumab, } \\
\text { sarilumab }\end{array}$ & \\
\hline & IL-12/23 inhibitor: & IL-1 receptor antagonist: anakinra & \\
\hline & ustekinumab & T-cell activation inhibitor: abatacept & \\
\hline & IL-23 inhibitor: guselkumab & CD20 inhibitor: rituximab & \\
\hline & $\begin{array}{l}\text { T-cell activation inhibitor: } \\
\text { abatacept }\end{array}$ & & \\
\hline \multirow[t]{2}{*}{ tsDMARDs } & PDE4 inhibitor: apremilast & JAK inhibitors: tofacitinib, & \\
\hline & JAK inhibitor: tofacitinib & baricitinib, upadacitinib & \\
\hline \multirow[t]{8}{*}{ Other } & Corticosteroid injections & Corticosteroid injections & Corticosteroid injections \\
\hline & NSAIDs & NSAIDs & NSAIDs \\
\hline & & & Opioids: tramadol \\
\hline & & & $\begin{array}{l}\text { Non-pharmacological } \\
\text { interventions: }\end{array}$ \\
\hline & & & Exercise \\
\hline & & & Weight management \\
\hline & & & Strength training \\
\hline & & & $\begin{array}{l}\text { Self-management and } \\
\text { education }\end{array}$ \\
\hline
\end{tabular}

bDMARD biologic DMARD, csDMARD conventional synthetic DMARD, DMARD disease-modifying antirheumatic drug, $I L$ interleukin, $J A K$ Janus kinase, $M T X$ methotrexate, NSAID nonsteroidal anti-inflammatory drug, $O A$ osteoarthritis, $P s A$ psoriatic arthritis, PDE4 phosphodiesterase 4, $R A$ rheumatoid arthritis, $T N F i$ tumor necrosis factor inhibitor, tsDMARD targeted synthetic DMARD

recommendations are also available for RA [146] and OA [147].

Approved treatment strategies differ because of the differences in pathogenesis, clinical presentation, and response to therapy among patients; therefore, an accurate disease diagnosis is imperative as it can have crucial implications for therapeutic response (Table 2). Treatments that are less specific, such as NSAIDs and corticosteroid injections, have been shown to be effective for treatment of the symptoms of PsA, RA [145], and OA [148, 149], and these agents could be used for initial disease management before a differential diagnosis and prognosis can be determined.

Once a diagnosis is established, it is imperative to consider which PsA disease domains are involved to select the appropriate treatment for 
Table 3 Recommended treatments for PsA by disease domain involvement $[3,105,144]$

\begin{tabular}{ll}
\hline Disease domain & Treatment recommendation $^{\mathbf{a}}$ \\
\hline Enthesitis $^{\mathrm{b}}$ & First line: NSAIDs, \\
& Inadequate response to NSAIDs: csDMARDs, TNFis, IL-12/23i, IL-17is, JAKi \\
Dactylitis $^{\mathrm{b}}$ & First line: csDMARDs \\
& Inadequate response to csDMARDs/TNFis: switch TNFis, IL-17is, IL-12/23i \\
& First line: csDMARDs, TNFis, NSAIDs, \\
& Inadequate response to prior DMARDs: IL-12/23i, IL-17is, JAKi \\
& Inadequate response to prior DMARDs with skin involvement: IL-17is, IL-12/23i \\
& First line: TNFis, IL-12/23i, IL-17i \\
Nail psoriasis & Inadequate response to prior biologics: switch biologic or PDE4i \\
Axial disease & First line: NSAIDs \\
& Inadequate response to prior NSAIDs: TNFis \\
& Inadequate response to prior NSAIDs with skin involvements: IL-17is \\
& First line: topical treatments, csDMARDs, particularly MTX \\
Psoriatic skin disease & Inadequate response to csDMARDs: IL-17is, IL-12/23i, TNFis, PDE4ic
\end{tabular}

LDMARD biologic DMARD, CS corticosteroids, csDMARD conventional synthetic DMARD, DMARD disease-modifying antirheumatic drug, $I L-12 / 23 i$ interleukin-12/23 inhibitor, $I L-17 i$ interleukin-17 inhibitor, JAKi Janus kinase inhibitor, $M T X$ methotrexate, NSAID nonsteroidal anti-inflammatory drug, PDE4i phosphodiesterase 4 inhibitor, PsA psoriatic arthritis, TNFi tumor necrosis factor inhibitor

a Treatment recommendations do not include evidence for IL-23 inhibitors, as none were approved for PsA at the time of their publication

b CS injections can be considered on an individual basis for peripheral arthritis, enthesitis, and dactylitis because of the potential for serious side effects and inadequate available evidence for efficacy

${ }^{c}$ In patients with mild disease

optimal effectiveness (Table 3) [105]. Data on the efficacy of csDMARDs, especially methotrexate, in PsA are varied; historically, methotrexate has not been shown to be effective for improving measures of synovitis, including joint counts, and ESR and CRP levels or for delaying radiographic progression but is effective for skin involvement seen with the disease. More recently, methotrexate has been shown to improve ACR20 responses among treatment-naive patients with PsA in randomized controlled trials [168-171]. Conversely, the efficacy of methotrexate in patients with RA is well established and is the most frequently used csDMARD for first-line therapy $[8,145]$. The use of csDMARDs in OA is less understood and the data are not robust enough to encourage incorporation of treatment into clinical practice; however, there is some evidence that methotrexate may be effective for pain reduction seen in OA of the knee $[172,173]$.

Therapeutic agents that target upstream factors, such as TNFis, are effective and recommended for the treatment of both RA and PsA $[105,145]$. TNFis are broadly effective; they are recommended to treat PsA-related enthesitis, dactylitis, and nail disease and are effective for PsA disease that is predominately axial. TNFis may be the preferred first and second bDMARDs for patients with concurrent uveitis [105, 144]. However, increasing evidence has shown that newer bDMARDs that block IL-17, IL-12/23, or 
IL-23 have increased efficacy and better longterm safety profiles compared with TNFis in PsA, particularly for skin and nail disease, with fewer adverse events [174-177]; these biologics are now recommended alongside TNFis for firstline therapy. IL-17 inhibitors may be preferred as first-line therapy for PsA with predominant skin involvement [176]. Additionally, IL-12/23 inhibitors do not show sufficient efficacy for axial involvement compared with TNFis, so they are not recommended when axial involvement is present [178]. These bDMARDs have shown superior efficacy for PsA treatment; however, the efficacy for RA is varied, and it has not been studied in OA $[179,180]$. Similarly, more selective bDMARDs have been increasingly shown to be more effective for the treatment of RA [146, 181]. Patients with RA will benefit from the use of bDMARDs that target IL6 and CD20, especially after inadequate response to TNFis, while their efficacy in patients with PsA is not established. Further, inhibition of $\mathrm{T}$ cell activation with abatacept treatment can be used in patients with RA, as well as those with PsA, who fail to respond to other bDMARDs.

For patients with an inadequate response to TNFis and other bDMARDs, tsDMARDs are increasingly recommended for patients with PsA (oral small molecules targeting JAK or PDE4) and RA (targeting JAK only). The efficacy of JAK inhibition in PsA has been established for patients with inadequate response or intolerance to csDMARDs and has been reported to significantly improve physical function, psoriasis, enthesitis, and dactylitis related to PsA $[165,182]$. Similarly, inhibiting PDE4 has been reported to significantly improve signs and symptoms of PsA and patient-reported outcome measures with sustained response up to 5 years regardless of prior bDMARD experience; however, inhibition of radiographic progression is not established with PDE4 inhibition [183, 184]. tsDMARDs effectively improve clinical manifestations, disease activity, and patient-related outcome measures of RA compared with csDMARDs, although greater improvements are achieved when administered in combination with csDMARDs [166, 181]. While efficacy of tsDMARDs has been recognized for both diseases, it is still important to differentiate PsA from RA for the consideration of tsDMARD treatment since some agents have not been thoroughly studied in PsA and may not be as effective as in RA. Although PsA, RA, and OA have various overlapping clinical manifestations, variations in underlying pathogenesis and response to therapy translate into significantly varying clinical outcomes.

\section{SUMMARY}

PsA is a complex disease characterized by inflammation of multiple clinical domains, including peripheral joints, skin and nails, axial joints, entheses, eyes, and digits. There are many systemic treatment options available that are dictated by disease severity and that have demonstrated effective control of joint damage as assessed by radiographic progression. Early assessment, diagnosis, and treat-to-target strategies are key to the management of patients with PsA to facilitate the administration of appropriate therapy in a timely manner. Skin manifestations of psoriasis, which often develop before arthritic symptoms, place the responsibility on the dermatologist or primary care provider to screen for arthritis and enhance early diagnosis. Collaboration and coordinated care are key among primary care providers and subspecialists to ensure positive outcomes for patients, controlling symptoms and disease activity, maintaining functional ability, and improving patient quality of life.

\section{ACKNOWLEDGMENTS}

Funding. Support for third-party writing assistance for this manuscript and the Rapid Service Fee was provided by Novartis.

\section{Medical Writing and Editorial} Assistance. The authors thank Linda GrinnellMerrick, NP, of Novartis Pharmaceuticals Corporation, East Hanover, NJ for providing medical expertise and content development, and Charli Dominguez, PhD, of Health Interactions, Inc, 
Chicago, IL, for providing medical writing support/editorial support; funding was provided by Novartis Pharmaceuticals Corporation, East Hanover, NJ, in accordance with Good Publication Practice (GPP3) guidelines (http://www. ismpp.org/gpp3). Authors had full control of the content and made the final decision on all aspects of this publication.

Authorship. All named authors meet the International Committee of Medical Journal Editors criteria for authorship for this article, take responsibility for the integrity of the work as a whole, and have given their approval for this version to be published.

Authorship Contributions. William Saalfeld, Amanda M. Mixon, Jonna Zelie, and Eileen J. Lydon were responsible for the conceptualization and design of the review, critically reviewing and revising all drafts of the review, and approving the final version of the manuscript.

Disclosures. W. Saalfeld received speaker and/or honoraria from Amgen (previously Celgene), Novartis, Pfizer, and Regeneron. A. M. Mixon received speaker fees/honoraria from AbbVie, Lilly, and Novartis, and has participated in an advisory board for Novartis. E. J. Lydon received speaker fees/honoraria from AbbVie and Sanofi. J. Zelie has nothing to disclose.

Compliance with Ethics Guidelines. This review is based on previously conducted studies and does not contain any studies with human participants or animals performed by any of the authors; therefore, ethical approval was not required.

Open Access. This article is licensed under a Creative Commons Attribution-NonCommercial 4.0 International License, which permits any non-commercial use, sharing, adaptation, distribution and reproduction in any medium or format, as long as you give appropriate credit to the original author(s) and the source, provide a link to the Creative Commons licence, and indicate if changes were made. The images or other third party material in this article are included in the article's Creative Commons licence, unless indicated otherwise in a credit line to the material. If material is not included in the article's Creative Commons licence and your intended use is not permitted by statutory regulation or exceeds the permitted use, you will need to obtain permission directly from the copyright holder. To view a copy of this licence, visit http://creativecommons.org/licenses/by$\mathrm{nc} / 4.0 /$.

\section{REFERENCES}

1. Mease PJ, Gladman DD, Papp KA, et al. Prevalence of rheumatologist-diagnosed psoriatic arthritis in patients with psoriasis in European/North American dermatology clinics. J Am Acad Dermatol. 2013;69(5):729-35.

2. Ogdie A, Weiss P. The epidemiology of psoriatic arthritis. Rheum Dis Clin North Am. 2015;41(4): 545-68.

3. Singh JA, Guyatt G, Ogdie A, et al. Special article: 2018 American College of Rheumatology/National Psoriasis Foundation Guideline for the treatment of psoriatic arthritis. Arthritis Care Res (Hoboken). 2019;71(1):2-29.

4. Gladman DD, Mease PJ, Healy P, et al. Outcome measures in psoriatic arthritis. J Rheumatol. 2007;34(5):1159-66.

5. Orbai AM, de Wit M, Mease P, et al. International patient and physician consensus on a psoriatic arthritis core outcome set for clinical trials. Ann Rheum Dis. 2017;76(4):673-80.

6. Gladman DD. Clinical features and diagnostic considerations in psoriatic arthritis. Rheum Dis Clin North Am. 2015;41(4):569-79.

7. McGonagle D, Hermann KG, Tan AL. Differentiation between osteoarthritis and psoriatic arthritis: implications for pathogenesis and treatment in the biologic therapy era. Rheumatology (Oxford). 2015;54(1):29-38.

8. Merola JF, Espinoza LR, Fleischmann R. Distinguishing rheumatoid arthritis from psoriatic arthritis. RMD Open. 2018;4(2):e000656.

9. Coates LC, FitzGerald O, Helliwell PS, Paul C. Psoriasis, psoriatic arthritis, and rheumatoid arthritis: is 
all inflammation the same? Semin Arthritis Rheum. 2016;46(3):291-304.

10. Smolen JS, Aletaha D, McInnes IB. Rheumatoid arthritis. Lancet. 2016;388(10055):2023-38.

11. Scott DL, Wolfe F, Huizinga TW. Rheumatoid arthritis. Lancet. 2010;376(9746):1094-108.

12. Safiri S, Kolahi AA, Hoy D, et al. Global, regional and national burden of rheumatoid arthritis 1990-2017: a systematic analysis of the Global Burden of Disease study 2017. Ann Rheum Dis. 2019;78(11):1463-71.

13. Glyn-Jones S, Palmer AJ, Agricola R, et al. Osteoarthritis. Lancet. 2015;386(9991):376-87.

14. Punzi L, Ramonda R, Sfriso P. Erosive osteoarthritis. Best Pract Res Clin Rheumatol. 2004;18(5):739-58.

15. Anandarajah A. Erosive osteoarthritis. Discov Med. 2010;9(48):468-77.

16. Gazeley DJ, Yeturi S, Patel PJ, Rosenthal AK. Erosive osteoarthritis: a systematic analysis of definitions used in the literature. Semin Arthritis Rheum. 2017;46(4):395-403.

17. Neogi T, Zhang Y. Epidemiology of osteoarthritis. Rheum Dis Clin North Am. 2013;39(1):1-19.

18. Oliveria SA, Felson DT, Reed JI, Cirillo PA, Walker AM. Incidence of symptomatic hand, hip, and knee osteoarthritis among patients in a health maintenance organization. Arthritis Rheum. 1995;38(8): $1134-41$.

19. Global Burden of Disease Study Collaborators. Global, regional, and national incidence, prevalence, and years lived with disability for 301 acute and chronic diseases and injuries in 188 countries, 1990-2013: a systematic analysis for the Global Burden of Disease Study 2013. Lancet. 2015;386(9995):743-800.

20. Haroon M, Gallagher P, FitzGerald O. Diagnostic delay of more than 6 months contributes to poor radiographic and functional outcome in psoriatic arthritis. Ann Rheum Dis. 2015;74(6):1045-50.

21. McHugh NJ, Balachrishnan C, Jones SM. Progression of peripheral joint disease in psoriatic arthritis: a 5-yr prospective study. Rheumatology (Oxford). 2003;42(6):778-83.

22. Ogdie A, Nowell WB, Applegate E, et al. Patient perspectives on the pathway to psoriatic arthritis diagnosis: results from a web-based survey of patients in the United States. BMC Rheumatol. 2020;4:2.
23. Taylor W, Gladman D, Helliwell P, et al. Classification criteria for psoriatic arthritis: development of new criteria from a large international study. Arthritis Rheum. 2006;54(8):2665-73.

24. Gottlieb A, Merola JF. Psoriatic arthritis for dermatologists. J Dermatolog Treat. 2020;31(7):662-79.

25. Mease PJ, Armstrong AW. Managing patients with psoriatic disease: the diagnosis and pharmacologic treatment of psoriatic arthritis in patients with psoriasis. Drugs. 2014;74(4):423-41.

26. Mease PJ, Karki C, Palmer JB, et al. Clinical and patient-reported outcomes in patients with psoriatic arthritis (PsA) by body surface area affected by psoriasis: results from the Corrona PsA/Spondyloarthritis registry. J Rheumatol. 2017;44(8):1151-8.

27. Schett G, Lories RJ, D'Agostino MA, et al. Enthesitis: from pathophysiology to treatment. Nat Rev Rheumatol. 2017;13(12):731-41.

28. Gladman DD, Ziouzina O, Thavaneswaran A, Chandran V. Dactylitis in psoriatic arthritis: prevalence and response to therapy in the biologic era. J Rheumatol. 2013;40(8):1357-9.

29. Brockbank JE, Stein M, Schentag CT, Gladman DD. Dactylitis in psoriatic arthritis: a marker for disease severity? Ann Rheum Dis. 2005;64(2):188-90.

30. Geijer M, Lindqvist U, Husmark T, et al. The Swedish Early Psoriatic Arthritis Registry 5-year followup: substantial radiographic progression mainly in men with high disease activity and development of dactylitis. J Rheumatol. 2015;42(11):2110-7.

31. Kaeley GS, Eder L, Aydin SZ, Gutierrez M, Bakewell C. Dactylitis: a hallmark of psoriatic arthritis. Semin Arthritis Rheum. 2018;48(2):263-73.

32. Chang CA, Gottlieb AB, Lizzul PF. Management of psoriatic arthritis from the view of the dermatologist. Nat Rev Rheumatol. 2011;7(10):588-98.

33. Gladman DD, Antoni C, Mease P, Clegg DO, Nash P. Psoriatic arthritis: epidemiology, clinical features, course, and outcome. Ann Rheum Dis. 2005;64 Suppl 2:ii14-17.

34. Reich K, Kruger K, Mossner R, Augustin M. Epidemiology and clinical pattern of psoriatic arthritis in Germany: a prospective interdisciplinary epidemiological study of 1511 patients with plaquetype psoriasis. Br J Dermatol. 2009;160(5):1040-7.

35. Wilson FC, Icen M, Crowson CS, McEvoy MT, Gabriel SE, Kremers HM. Incidence and clinical predictors of psoriatic arthritis in patients with 
psoriasis: a population-based study. Arthritis Rheum. 2009;61(2):233-9.

36. Sandre MK, Rohekar S. Psoriatic arthritis and nail changes: exploring the relationship. Semin Arthritis Rheum. 2014;44(2):162-9.

37. Kaeley GS, Eder L, Aydin SZ, Rich P, Bakewell CJ. Nail psoriasis: diagnosis, assessment, treatment options, and unmet clinical needs. J Rheumatol. 2021;48(8):1208-20.

38. de Berker D. Management of psoriatic nail disease. Semin Cutan Med Surg. 2009;28(1):39-43.

39. Jiaravuthisan MM, Sasseville D, Vender RB, Murphy F, Muhn CY. Psoriasis of the nail: anatomy, pathology, clinical presentation, and a review of the literature on therapy. J Am Acad Dermatol. 2007;57(1):1-27.

40. Raposo I, Torres T. Nail psoriasis as a predictor of the development of psoriatic arthritis. Actas Dermosifiliogr. 2015;106(6):452-7.

41. Cimmino MA, Seriolo B, Accardo S. Prevalence of nail involvement in nodal osteoarthritis. Clin Rheumatol. 1994;13(2):203-6.

42. Kalyoncu U, Gossec L, Nguyen M, et al. Self-reported prevalence of psoriasis and evaluation of the impact on the natural history of hip osteoarthritis: results of a 10 years follow-up study of 507 patients (ECHODIAH study). Joint Bone Spine. 2009;76(4): 389-93.

43. Moller I, Perez M, Monfort J, et al. Effectiveness of chondroitin sulphate in patients with concomitant knee osteoarthritis and psoriasis: a randomized, double-blind, placebo-controlled study. Osteoarthritis Cartilage. 2010;18(Suppl 1):S32-40.

44. Wright V. Psoriatic arthritis. A comparative radiographic study of rheumatoid arthritis and arthritis associated with psoriasis. Ann Rheum Dis. 1961;20: 123-132.

45. Gottlieb A, Korman NJ, Gordon KB, et al. Guidelines of care for the management of psoriasis and psoriatic arthritis: Section 2. Psoriatic arthritis: overview and guidelines of care for treatment with an emphasis on the biologics. J Am Acad Dermatol. 2008;58(5):851-864.

46. Sobolewski P, Walecka I, Dopytalska K. Nail involvement in psoriatic arthritis. Reumatologia. 2017;55(3):131-5.

47. Gottlieb AB, Merola JF. Axial psoriatic arthritis: an update for dermatologists. J Am Acad Dermatol. 2021;84(1):92-101.
48. Gladman DD. Axial psoriatic arthritis. Curr Rheumatol Rep. 2021;23(6):35.

49. Chandran V, Tolusso DC, Cook RJ, Gladman DD. Risk factors for axial inflammatory arthritis in patients with psoriatic arthritis. J Rheumatol. 2010;37(4):809-15.

50. Grinnell-Merrick LL, Lydon EJ, Mixon AM, Saalfeld W. Evaluating inflammatory versus mechanical back pain in individuals with psoriatic arthritis: a review of the literature. Rheumatol Ther. 2020;7(4): 667-84.

51. Lindstrom U, Bremander A, Haglund E, Bergman S, Petersson IF, Jacobsson LT. Back pain and health status in patients with clinically diagnosed ankylosing spondylitis, psoriatic arthritis and other spondyloarthritis: a cross-sectional populationbased study. BMC Musculoskelet Disord. 2016;17: 106.

52. Caso F, Costa L, Atteno M, et al. Simple clinical indicators for early psoriatic arthritis detection. Springerplus. 2014;3:759.

53. Baraliakos X, Coates LC, Braun J. The involvement of the spine in psoriatic arthritis. Clin Exp Rheumatol. 2015;33(5 Suppl 93):S31-35.

54. Sieper J, Rudwaleit M, Baraliakos X, et al. The Assessment of SpondyloArthritis international Society (ASAS) handbook: a guide to assess spondyloarthritis. Ann Rheum Dis. 2009;68 Suppl 2:ii1-44.

55. Sieper J, van der Heijde D, Landewe R, et al. New criteria for inflammatory back pain in patients with chronic back pain: a real patient exercise by experts from the assessment of SpondyloArthritis international Society (ASAS). Ann Rheum Dis. 2009;68(6): 784-8.

56. Burgos-Vargas R, Braun J. Inflammatory back pain. Rheum Dis Clin North Am. 2012;38(3):487-99.

57. Ledford C. Spine conditions: mechanical and inflammatory low back pain. FP Essent. 2017;461: 15-20.

58. Castillo-Gallego C, Aydin SZ, Emery P, McGonagle DG, Marzo-Ortega H. Magnetic resonance imaging assessment of axial psoriatic arthritis: extent of disease relates to HLA-B27. Arthritis Rheum. 2013;65(9):2274-8.

59. Michelena X, Poddubnyy D, Marzo-Ortega H. Axial psoriatic arthritis: a distinct clinical entity in search of a definition. Rheum Dis Clin North Am. 2020;46(2):327-41. 
60. Lubrano E, Parsons WJ, Marchesoni A, et al. The definition and measurement of axial psoriatic arthritis. J Rheumatol Suppl. 2015;93:40-2.

61. Sudol-Szopinska I, Matuszewska G, Kwiatkowska B, Pracon G. Diagnostic imaging of psoriatic arthritis. Part I: etiopathogenesis, classifications and radiographic features. J Ultrason. 2016;16(64):65-77.

62. Labitigan M, Bahce-Altuntas A, Kremer JM, et al. Higher rates and clustering of abnormal lipids, obesity, and diabetes mellitus in psoriatic arthritis compared with rheumatoid arthritis. Arthritis Care Res (Hoboken). 2014;66(4):600-7.

63. Kaine J, Song X, Kim G, Hur P, Palmer JB. Higher incidence rates of comorbidities in patients with psoriatic arthritis compared with the general population using U.S. administrative claims data. J Manag Care Spec Pharm. 2019;25(1):122-132.

64. Shah K, Paris M, Mellars L, Changolkar A, Mease PJ. Real-world burden of comorbidities in US patients with psoriatic arthritis. RMD Open. 2017;3(2): e000588.

65. Jamnitski A, Visman IM, Peters MJ, Boers M, Dijkmans BA, Nurmohamed MT. Prevalence of cardiovascular diseases in psoriatic arthritis resembles that of rheumatoid arthritis. Ann Rheum Dis. 2011;70(5):875-6.

66. Mease PJ, Liu M, Rebello S, et al. Comparative disease burden in patients with rheumatoid arthritis, psoriatic arthritis, or axial spondyloarthritis: data from two Corrona registries. Rheumatol Ther. 2019;6(4):529-42.

67. Ogdie A, Yu Y, Haynes K, et al. Risk of major cardiovascular events in patients with psoriatic arthritis, psoriasis and rheumatoid arthritis: a populationbased cohort study. Ann Rheum Dis. 2015;74(2): 326-32.

68. Canete JD, Mease P. The link between obesity and psoriatic arthritis. Ann Rheum Dis. 2012;71(8): 1265-6.

69. Deveza LA, Melo L, Yamato TP, Mills K, Ravi V, Hunter DJ. Knee osteoarthritis phenotypes and their relevance for outcomes: a systematic review. Osteoarthritis Cartilage. 2017;25(12):1926-41.

70. Schieir O, Tosevski C, Glazier RH, Hogg-Johnson S, Badley EM. Incident myocardial infarction associated with major types of arthritis in the general population: a systematic review and meta-analysis. Ann Rheum Dis. 2017;76(8):1396-404.

71. Yusuf E. Metabolic factors in osteoarthritis: obese people do not walk on their hands. Arthritis Res Ther. 2012;14(4):123.
72. Swain S, Sarmanova A, Coupland C, Doherty M, Zhang W. Comorbidities in osteoarthritis: a systematic review and meta-analysis of observational studies. Arthritis Care Res (Hoboken). 2020;72(7): 991-1000.

73. van der Heijde D, Gladman DD, Kavanaugh A, Mease PJ. Assessing structural damage progression in psoriatic arthritis and its role as an outcome in research. Arthritis Res Ther. 2020;22(1):18.

74. Wassenberg S. Radiographic scoring methods in psoriatic arthritis. Clin Exp Rheumatol. 2015;33(5 Suppl 93):S55-59.

75. Braga MV, de Oliveira SC, Vasconcelos AHC, et al. Prevalence of sacroiliitis and acute and structural changes on MRI in patients with psoriatic arthritis. Sci Rep. 2020;10(1):11580.

76. Ritchlin CT, Colbert RA, Gladman DD. Psoriatic arthritis. N Engl J Med. 2017;376(10):957-70.

77. D'Agostino MA, Terslev L. Imaging evaluation of the entheses: ultrasonography, MRI, and scoring of evaluation. Rheum Dis Clin North Am. 2016;42(4): 679-93.

78. Watad A, Eshed I, McGonagle D. Lessons learned from imaging on enthesitis in psoriatic arthritis. Isr Med Assoc J. 2017;19(11):708-11.

79. Ichikawa N, Taniguchi A, Kobayashi S, Yamanaka H. Performance of hands and feet radiographs in differentiation of psoriatic arthritis from rheumatoid arthritis. Int J Rheum Dis. 2012;15(5):462-7.

80. Bakewell C, Aydin SZ, Ranganath VK, Eder L, Kaeley GS. Imaging techniques: options for the diagnosis and monitoring of treatment of enthesitis in psoriatic arthritis. J Rheumatol. 2020;47(7):973-82.

81. Naredo E, Moller I, de Miguel E, et al. High prevalence of ultrasonographic synovitis and enthesopathy in patients with psoriasis without psoriatic arthritis: a prospective case-control study. Rheumatology (Oxford). 2011;50(10):1838-48.

82. Zuliani F, Zabotti A, Errichetti E, et al. Ultrasonographic detection of subclinical enthesitis and synovitis: a possible stratification of psoriatic patients without clinical musculoskeletal involvement. Clin Exp Rheumatol. 2019;37(4):593-9.

83. D'Agostino MA, Terslev L, Aegerter P, et al. Scoring ultrasound synovitis in rheumatoid arthritis: a EULAR-OMERACT ultrasound taskforce-Part 1: definition and development of a standardised, consensus-based scoring system. RMD Open. 2017;3(1):e000428 
84. Bandinelli F, Denaro V, Prignano F, Collaku L, Ciancio G, Matucci-Cerinic M. Ultrasonographic wrist and hand abnormalities in early psoriatic arthritis patients: correlation with clinical, dermatological, serological and genetic indices. Clin Exp Rheumatol. 2015;33(3):330-5.

85. Freeston JE, Coates LC, Nam JL, et al. Is there subclinical synovitis in early psoriatic arthritis? A clinical comparison with gray-scale and power Doppler ultrasound. Arthritis Care Res (Hoboken). 2014;66(3):432-9.

86. Kamel M, Eid H, Mansour R. Ultrasound detection of heel enthesitis: a comparison with magnetic resonance imaging. J Rheumatol. 2003;30(4):774-8.

87. Balint PV, Kane D, Wilson H, McInnes IB, Sturrock RD. Ultrasonography of entheseal insertions in the lower limb in spondyloarthropathy. Ann Rheum Dis. 2002;61(10):905-10.

88. Tom S, Zhong Y, Cook R, Aydin SZ, Kaeley G, Eder L. Development of a preliminary ultrasonographic enthesitis score in psoriatic arthritis-GRAPPA Ultrasound Working Group. J Rheumatol. 2019;46(4):384-90.

89. Polachek A, Li S, Chandran V, Gladman DD. Clinical enthesitis in a prospective longitudinal psoriatic arthritis cohort: incidence, prevalence, characteristics, and outcome. Arthritis Care Res (Hoboken). 2017;69(11):1685-91.

90. Gutierrez M, Filippucci E, Salaffi F, Di Geso L, Grassi W. Differential diagnosis between rheumatoid arthritis and psoriatic arthritis: the value of ultrasound findings at metacarpophalangeal joints level. Ann Rheum Dis. 2011;70(6):1111-4.

91. Wiell C, Szkudlarek M, Hasselquist M, et al. Ultrasonography, magnetic resonance imaging, radiography, and clinical assessment of inflammatory and destructive changes in fingers and toes of patients with psoriatic arthritis. Arthritis Res Ther. 2007;9(6):R119.

92. Ostergaard M, McQueen F, Wiell C, et al. The OMERACT psoriatic arthritis magnetic resonance imaging scoring system (PsAMRIS): definitions of key pathologies, suggested MRI sequences, and preliminary scoring system for PsA hands. J Rheumatol. 2009;36(8):1816-24.

93. Sankowski AJ, Lebkowska UM, Cwikla J, Walecka I, Walecki J. The comparison of efficacy of different imaging techniques (conventional radiography, ultrasonography, magnetic resonance) in assessment of wrist joints and metacarpophalangeal joints in patients with psoriatic arthritis. Pol J Radiol. 2013;78(1):18-29.
94. Mathew AJ, Coates LC, Danda D, Conaghan PG. Psoriatic arthritis: lessons from imaging studies and implications for therapy. Expert Rev Clin Immunol. 2017;13(2):133-42.

95. Narvaez J, Narvaez JA, de Albert M, Gomez-Vaquero C, Nolla JM. Can magnetic resonance imaging of the hand and wrist differentiate between rheumatoid arthritis and psoriatic arthritis in the early stages of the disease? Semin Arthritis Rheum. 2012;42(3):234-45.

96. Braum LS, McGonagle D, Bruns A, et al. Characterisation of hand small joints arthropathy using highresolution MRI-limited discrimination between osteoarthritis and psoriatic arthritis. Eur Radiol. 2013;23(6):1686-93.

97. Felbo SK, Terslev L, Ostergaard M. Imaging in peripheral and axial psoriatic arthritis: contributions to diagnosis, follow-up, prognosis and knowledge of pathogenesis. Clin Exp Rheumatol. 2018;36 Suppl 114(5):24-34.

98. Forney MC, Winalski CS, Schils JP. Magnetic resonance imaging of inflammatory arthropathies of peripheral joints. Top Magn Reson Imaging. $2011 ; 22(2): 45-59$.

99. Schraml C, Schwenzer NF, Martirosian P, et al. Assessment of synovitis in erosive osteoarthritis of the hand using DCE-MRI and comparison with that in its major mimic, the psoriatic arthritis. Acad Radiol. 2011;18(7):804-9.

100. Bagel J, Schwartzman S. Enthesitis and dactylitis in psoriatic disease: a guide for dermatologists. Am J Clin Dermatol. 2018;19(6):839-52.

101. Mandl P, Navarro-Compan V, Terslev L, et al. EULAR recommendations for the use of imaging in the diagnosis and management of spondyloarthritis in clinical practice. Ann Rheum Dis. 2015;74(7): 1327-39.

102. Veale DJ, Fearon U. What makes psoriatic and rheumatoid arthritis so different? RMD Open. 2015;1(1):e000025.

103. Donmez S, Pamuk ON, Akker M, Ak R. Clinical features and types of articular involvement in patients with psoriatic arthritis. Clin Rheumatol. 2015;34(6):1091-6.

104. Ogdie A, Coates LC, Gladman DD. Treatment guidelines in psoriatic arthritis. Rheumatology (Oxford). 2020;59(Supplement_1):i37-i46.

105. Gossec L, Baraliakos X, Kerschbaumer A, et al. EULAR recommendations for the management of psoriatic arthritis with pharmacological therapies: 2019 update. Ann Rheum Dis. 2020;79(6):700-12. 
106. Generali E, Scire CA, Favalli EG, Selmi C. Biomarkers in psoriatic arthritis: a systematic literature review. Expert Rev Clin Immunol. 2016;12(6): 651-60.

107. Winchester R, Minevich G, Steshenko V, et al. HLA associations reveal genetic heterogeneity in psoriatic arthritis and in the psoriasis phenotype. Arthritis Rheum. 2012;64(4):1134-44.

108. Haroon M, Winchester R, Giles JT, Heffernan E, FitzGerald O. Certain class I HLA alleles and haplotypes implicated in susceptibility play a role in determining specific features of the psoriatic arthritis phenotype. Ann Rheum Dis. 2016;75(1): 155-62.

109. Queiro R, Morante I, Cabezas I, Acasuso B. HLA-B27 and psoriatic disease: a modern view of an old relationship. Rheumatology (Oxford). 2016;55(2): 221-9.

110. Silman AJ, Pearson JE. Epidemiology and genetics of rheumatoid arthritis. Arthritis Res. 2002;4(Suppl 3): S265-272.

111. Ahmad T, Marshall SE, Jewell D. Genetics of inflammatory bowel disease: the role of the HLA complex. World J Gastroenterol. 2006;12(23): 3628-35.

112. Bazzoni F, Beutler B. The tumor necrosis factor ligand and receptor families. $\mathrm{N}$ Engl J Med. 1996;334(26):1717-25.

113. Bradley JR. TNF-mediated inflammatory disease. J Pathol. 2008;214(2):149-60.

114. van Kuijk AW, Reinders-Blankert P, Smeets TJ, Dijkmans BA, Tak PP. Detailed analysis of the cell infiltrate and the expression of mediators of synovial inflammation and joint destruction in the synovium of patients with psoriatic arthritis: implications for treatment. Ann Rheum Dis. 2006;65(12):1551-1557.

115. Blauvelt A, Chiricozzi A. The Immunologic role of IL-17 in psoriasis and psoriatic arthritis pathogenesis. Clin Rev Allergy Immunol. 2018;55(3):379-90.

116. de Vlam K, Gottlieb AB, Mease PJ. Current concepts in psoriatic arthritis: pathogenesis and management. Acta Derm Venereol. 2014;94(6):627-34.

117. Raychaudhuri SP. Role of IL-17 in psoriasis and psoriatic arthritis. Clin Rev Allergy Immunol. 2013;44(2):183-93.

118. Raychaudhuri SP, Raychaudhuri SK, Genovese MC. IL-17 receptor and its functional significance in psoriatic arthritis. Mol Cell Biochem. 2012;359(1-2):419-29.
119. Filer C, Ho P, Smith RL, et al. Investigation of association of the IL12B and IL23R genes with psoriatic arthritis. Arthritis Rheum. 2008;58(12): 3705-9.

120. Huffmeier U, Lascorz J, Bohm B, et al. Genetic variants of the IL-23R pathway: association with psoriatic arthritis and psoriasis vulgaris, but no specific risk factor for arthritis. J Invest Dermatol. 2009;129(2):355-8.

121. Athie-Morales V, Smits HH, Cantrell DA, Hilkens CM. Sustained IL-12 signaling is required for Th1 development. J Immunol. 2004;172(1):61-9.

122. Sherlock JP, Joyce-Shaikh B, Turner SP, et al. IL-23 induces spondyloarthropathy by acting on ROR- $\gamma+$ CD3+CD4-CD8- entheseal resident $\mathrm{T}$ cells. Nat Med. 2012;18(7):1069-76.

123. Lories RJ, McInnes IB. Primed for inflammation: enthesis-resident T cells. Nat Med. 2012;18(7): 1018-9.

124. Choy E. Understanding the dynamics: pathways involved in the pathogenesis of rheumatoid arthritis. Rheumatology (Oxford). 2012;51(Suppl 5):v311.

125. McInnes IB, Schett G. Cytokines in the pathogenesis of rheumatoid arthritis. Nat Rev Immunol. 2007;7(6):429-42.

126. Smolen JS, Steiner G. Therapeutic strategies for rheumatoid arthritis. Nat Rev Drug Discov. 2003;2(6):473-88.

127. Livshits G, Zhai G, Hart DJ, et al. Interleukin-6 is a significant predictor of radiographic knee osteoarthritis: The Chingford Study. Arthritis Rheum. 2009;60(7):2037-45.

128. Celis R, Planell N, Fernandez-Sueiro JL, et al. Synovial cytokine expression in psoriatic arthritis and associations with lymphoid neogenesis and clinical features. Arthritis Res Ther. 2012;14(2):R93.

129. Dinarello CA. Overview of the interleukin-1 family of ligands and receptors. Semin Immunol. 2013;25(6):389-93.

130. Mueller MB, Tuan RS. Anabolic/Catabolic balance in pathogenesis of osteoarthritis: identifying molecular targets. PM R. 2011;3(6 Suppl 1):S3-11.

131. Wojdasiewicz P, Poniatowski LA, Szukiewicz D. The role of inflammatory and anti-inflammatory cytokines in the pathogenesis of osteoarthritis. Mediators Inflamm. 2014;2014:561459. 
132. Dinarello CA, van der Meer JW. Treating inflammation by blocking interleukin-1 in humans. Semin Immunol. 2013;25(6):469-84.

133. Avdeeva A, Rubtsov Y, Dyikanov D, Popkova T, Nasonov E. Regulatory T cells in patients with early untreated rheumatoid arthritis: phenotypic changes in the course of methotrexate treatment. Biochimie. 2020;174:9-17.

134. Choy E. T cells in psoriatic arthritis. Curr Rheumatol Rep. 2007;9(6):437-41.

135. Diani M, Casciano F, Marongiu L, et al. Increased frequency of activated CD8(+) T cell effectors in patients with psoriatic arthritis. Sci Rep. 2019;9(1): 10870.

136. El Jammal T, Gerfaud-Valentin M, Seve P, Jamilloux Y. Inhibition of JAK/STAT signaling in rheumatologic disorders: the expanding spectrum. Joint Bone Spine. 2020;87(2):119-29.

137. Veale DJ, McGonagle D, McInnes IB, et al. The rationale for Janus kinase inhibitors for the treatment of spondyloarthritis. Rheumatology (Oxford). 2019;58(2):197-205.

138. Ghoreschi K, Laurence A, O'Shea JJ. Janus kinases in immune cell signaling. Immunol Rev. 2009;228(1): 273-87.

139. O'Shea JJ, Kontzias A, Yamaoka K, Tanaka Y, Laurence A. Janus kinase inhibitors in autoimmune diseases. Ann Rheum Dis. 2013;72 Suppl 2: ii111-115.

140. O'Sullivan LA, Liongue C, Lewis RS, Stephenson SE, Ward AC. Cytokine receptor signaling through the Jak-Stat-Socs pathway in disease. Mol Immunol. 2007;44(10):2497-506.

141. Hodge JA, Kawabata TT, Krishnaswami S, et al. The mechanism of action of tofacitinib - an oral Janus kinase inhibitor for the treatment of rheumatoid arthritis. Clin Exp Rheumatol. 2016;34(2):318-28.

142. Wervers K, Luime JJ, Tchetverikov I, et al. Influence of disease manifestations on health-related quality of life in early psoriatic arthritis. J Rheumatol. 2018;45(11):1526-31.

143. Ogdie A, Hur P, Liu M, et al. Impact of multidomain disease presentations on patients with psoriatic arthritis in the Corrona Psoriatic Arthritis/Spondyloarthritis registry. J Rheumatol. 2021;48(5): 698-706.

144. Coates LC, Kavanaugh A, Mease PJ, et al. Group for Research and Assessment of Psoriasis and Psoriatic Arthritis 2015 treatment recommendations for psoriatic arthritis. Arthritis Rheumatol. 2016;68(5): 1060-71.

145. Singh JA, Saag KG, Bridges SL Jr, et al. 2015 American College of Rheumatology guideline for the treatment of rheumatoid arthritis. Arthritis Rheumatol. 2016;68(1):1-26.

146. Smolen JS, Landewe RBM, Bijlsma JWJ, et al. EULAR recommendations for the management of rheumatoid arthritis with synthetic and biological diseasemodifying antirheumatic drugs: 2019 update. Ann Rheum Dis. 2020;79(6):685-99.

147. Bannuru RR, Osani MC, Vaysbrot EE, et al. OARSI guidelines for the non-surgical management of knee, hip, and polyarticular osteoarthritis. Osteoarthritis Cartilage. 2019;27(11):1578-89.

148. Hermann W, Lambova S, Muller-Ladner U. Current treatment options for osteoarthritis. Curr Rheumatol Rev. 2018;14(2):108-16.

149. Nelson AE, Allen KD, Golightly YM, Goode AP, Jordan JM. A systematic review of recommendations and guidelines for the management of osteoarthritis: the chronic osteoarthritis management initiative of the U.S. bone and joint initiative. Semin Arthritis Rheum. 2014;43(6):701-712.

150. Persson MSM, Sarmanova A, Doherty M, Zhang W. Conventional and biologic disease-modifying antirheumatic drugs for osteoarthritis: a meta-analysis of randomized controlled trials. Rheumatology (Oxford). 2018;57(10):1830-7.

151. McInnes IB, Mease PJ, Kirkham B, et al. Secukinumab, a human anti-interleukin-17A monoclonal antibody, in patients with psoriatic arthritis (FUTURE 2): a randomised, double-blind, placebocontrolled, phase 3 trial. Lancet. 2015;386(9999): 1137-46.

152. Mease PJ, McInnes IB, Kirkham B, et al. Secukinumab inhibition of interleukin-17A in patients with psoriatic arthritis. N Engl J Med. 2015;373(14): 1329-39.

153. McInnes IB, Kavanaugh A, Gottlieb AB, et al. Efficacy and safety of ustekinumab in patients with active psoriatic arthritis: 1 year results of the phase 3 , multicentre, double-blind, placebo-controlled PSUMMIT 1 trial. Lancet. 2013;382(9894):780-9.

154. Mease PJ, van der Heijde D, Ritchlin CT, et al. Ixekizumab, an interleukin-17A specific monoclonal antibody, for the treatment of biologic-naive patients with active psoriatic arthritis: results from the 24-week randomised, double-blind, placebocontrolled and active (adalimumab)-controlled period of the phase III trial SPIRIT-P1. Ann Rheum Dis. 2017;76(1):79-87. 
155. Nash P, Kirkham B, Okada M, et al. Ixekizumab for the treatment of patients with active psoriatic arthritis and an inadequate response to tumour necrosis factor inhibitors: results from the 24-week randomised, double-blind, placebo-controlled period of the SPIRIT-P2 phase 3 trial. Lancet. 2017;389(10086):2317-27.

156. Ritchlin C, Rahman P, Kavanaugh A, et al. Efficacy and safety of the anti-IL-12/23 p40 monoclonal antibody, ustekinumab, in patients with active psoriatic arthritis despite conventional non-biological and biological anti-tumour necrosis factor therapy: 6-month and 1-year results of the phase 3, multicentre, double-blind, placebo-controlled, randomised PSUMMIT 2 trial. Ann Rheum Dis. 2014;73(6):990-9.

157. Deodhar A, Helliwell PS, Boehncke WH, et al. Guselkumab in patients with active psoriatic arthritis who were biologic-naive or had previously received TNF $\alpha$ inhibitor treatment (DISCOVER-1): a double-blind, randomised, placebo-controlled phase 3 trial. Lancet. 2020;395(10230):1115-25.

158. Mease PJ, Rahman P, Gottlieb AB, et al. Guselkumab in biologic-naive patients with active psoriatic arthritis (DISCOVER-2): a double-blind, randomised, placebo-controlled phase 3 trial. Lancet. 2020;395(10230):1126-36.

159. Abbasi M, Mousavi MJ, Jamalzehi S, et al. Strategies toward rheumatoid arthritis therapy; the old and the new. J Cell Physiol. 2019;234(7):10018-31.

160. Nikfar S, Saiyarsarai P, Tigabu BM, Abdollahi M. Efficacy and safety of interleukin-1 antagonists in rheumatoid arthritis: a systematic review and metaanalysis. Rheumatol Int. 2018;38(8):1363-83.

161. Tavakolpour S, Alesaeidi S, Darvishi M, et al. A comprehensive review of rituximab therapy in rheumatoid arthritis patients. Clin Rheumatol. 2019;38(11):2977-94.

162. Scott LJ. Tocilizumab: a review in rheumatoid arthritis. Drugs. 2017;77(17):1865-79.

163. Genovese MC, Pacheco-Tena C, Covarrubias A, et al. Longterm safety and efficacy of subcutaneous abatacept in patients with rheumatoid arthritis: 5 -year results from a phase IIIb trial. J Rheumatol. 2018;45(8):1085-92.

164. Mease PJ, Gottlieb AB, van der Heijde D, et al. Efficacy and safety of abatacept, a T-cell modulator, in a randomised, double-blind, placebo-controlled, phase III study in psoriatic arthritis. Ann Rheum Dis. 2017;76(9):1550-8.

165. Berekmeri A, Mahmood F, Wittmann M, Helliwell P. Tofacitinib for the treatment of psoriasis and psoriatic arthritis. Expert Rev Clin Immunol. 2018;14(9):719-30.

166. Fleischmann R, Kremer J, Cush J, et al. Placebocontrolled trial of tofacitinib monotherapy in rheumatoid arthritis. N Engl J Med. 2012;367(6): 495-507.

167. Schett G, Wollenhaupt J, Papp K, et al. Oral apremilast in the treatment of active psoriatic arthritis: results of a multicenter, randomized, double-blind, placebo-controlled study. Arthritis Rheum. 2012;64(10):3156-67.

168. Abu-Shakra M, Gladman DD, Thorne JC, Long J, Gough J, Farewell VT. Longterm methotrexate therapy in psoriatic arthritis: clinical and radiological outcome. J Rheumatol. 1995;22(2):241-5.

169. Kingsley GH, Kowalczyk A, Taylor H, et al. A randomized placebo-controlled trial of methotrexate in psoriatic arthritis. Rheumatology (Oxford). 2012;51(8):1368-77.

170. Willkens RF, Williams HJ, Ward JR, et al. Randomized, double-blind, placebo controlled trial of lowdose pulse methotrexate in psoriatic arthritis. Arthritis Rheum. 1984;27(4):376-81.

171. Mease PJ, Gladman DD, Collier DH, et al. Etanercept and methotrexate as monotherapy or in combination for psoriatic arthritis: primary results from a randomized, controlled phase III trial. Arthritis Rheumatol. 2019;71(7):1112-24.

172. El Miedany Y, El Gaafary M, Youssef S, Ahmed I, Nasr A. Tailored approach to early psoriatic arthritis patients: clinical and ultrasonographic predictors for structural joint damage. Clin Rheumatol. 2015;34(2):307-13.

173. Kalunian KC. Current advances in therapies for osteoarthritis. Curr Opin Rheumatol. 2016;28(3): 246-50.

174. McInnes IB, Nash P, Ritchlin C, et al. Secukinumab for psoriatic arthritis: comparative effectiveness versus licensed biologics/apremilast: a network meta-analysis. J Comp Eff Res. 2018;7(11):1107-23.

175. Mease P, Choy E, Nash P, et al. Comparative effectiveness of secukinumab and etanercept in biologicnaive patients with psoriatic arthritis assessed by matching-adjusted indirect comparison. Eur J Rheumatol. 2019;6(3):113-21.

176. Mease PJ, Smolen JS, Behrens F, et al. A head-tohead comparison of the efficacy and safety of ixekizumab and adalimumab in biological-naive patients with active psoriatic arthritis: 24-week results of a randomised, open-label, blinded-assessor trial. Ann Rheum Dis. 2020;79(1):123-31. 
177. McInnes IB, Behrens F, Mease PJ, et al. Secukinumab versus adalimumab for treatment of active psoriatic arthritis (EXCEED): a double-blind, parallel-group, randomised, active-controlled, phase $3 \mathrm{~b}$ trial. Lancet. 2020;395(10235):1496-505.

178. Siebert S, Millar NL, McInnes IB. Why did IL-23p19 inhibition fail in AS: a tale of tissues, trials or translation? Ann Rheum Dis. 2019;78(8):1015-8.

179. Genovese MC, Durez P, Richards HB, et al. Efficacy and safety of secukinumab in patients with rheumatoid arthritis: a phase II, dose-finding, double-blind, randomised, placebo controlled study. Ann Rheum Dis. 2013;72(6):863-9.

180. Kerschbaumer A, Sepriano A, Smolen JS, et al. Efficacy of pharmacological treatment in rheumatoid arthritis: a systematic literature research informing the 2019 update of the EULAR recommendations for management of rheumatoid arthritis. Ann Rheum Dis. 2020;79(6):744-59.
181. Emery P, Pope JE, Kruger K, et al. Efficacy of monotherapy with biologics and JAK inhibitors for the treatment of rheumatoid arthritis: a systematic review. Adv Ther. 2018;35(10):1535-63.

182. Gladman D, Rigby W, Azevedo VF, et al. Tofacitinib for psoriatic arthritis in patients with an inadequate response to TNF inhibitors. $\mathrm{N}$ Engl J Med. 2017;377(16):1525-36.

183. Edwards CJ, Blanco FJ, Crowley J, et al. Apremilast, an oral phosphodiesterase 4 inhibitor, in patients with psoriatic arthritis and current skin involvement: a phase III, randomised, controlled trial (PALACE 3). Ann Rheum Dis. 2016;75(6):1065-73.

184. Kavanaugh A, Mease PJ, Gomez-Reino JJ, et al. Treatment of psoriatic arthritis in a phase 3 randomised, placebo-controlled trial with apremilast, an oral phosphodiesterase 4 inhibitor. Ann Rheum Dis. 2014;73(6):1020-6. 